\title{
Framed! The Failure of Traditional Agency Cost EXPlanations for EXecutive Pay Practices
}

\author{
BRYCE C. TINGLE*
}

\begin{abstract}
This is the second article in a series exploring the empirical evidence arising from the increasing use of certain executive compensation best practices. The first article, "How Good Are Our 'Best Practices' When It Comes to Executive Compensation?” summarizes research findings that these best practices are responsible for most of the growth in executive compensation, and lead to suboptimal corporate performance. It also suggests that the best practices currently in widespread use contradict practices that are often very helpful to directors in setting appropriate incentives in real world circumstances.
\end{abstract}

This article goes on to argue that failures in executive compensation are the result, not of overly powerful CEOs confronting supine boards, but rather of directors and management earnestly striving to follow bad "best practices" promulgated by the corporate governance industry. This can be seen in: (1) the pattern of cause and effect distinguishable in the history of changing North American and British pay practices; (2) the link between these questionable pay practices and various measures of board independence and managerial weakness; and (3) the increasing use of these pay practices in circumstances of increased shareholder power. The most obvious solution is to increase board autonomy in setting pay. Regulatory steps for doing so lay close at hand, and in some cases have been discussed for years.

\section{TABLE OF CONTENTS}

I. INTRODUCTION . . . . . . . . . . . . . . . . . . . . . . . . . . . 899

II. THE Role OF EXECUTIVE COMPENSATION IN Current Discussions of Corporate Governance . . . . . . . . . 900

A. The Agency Cost Explanation . . . . . . . . . . . . . 901

III. EMPIRICAL EVIDENCE ABOUT CERTAIN

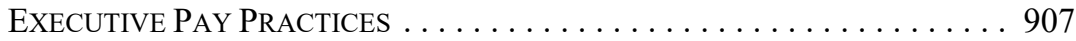

IV. Who SETS EXECUTIVE PAy? . . . . . . . . . . . . . . . . 913

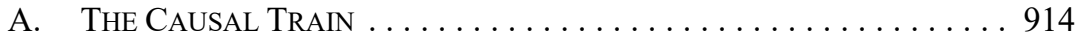

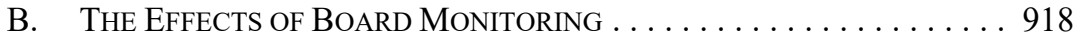

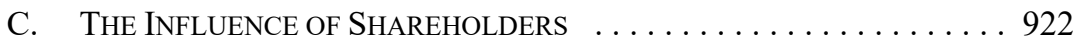

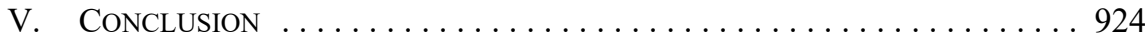

\section{INTRODUCTION}

There is a narrative that underlies nearly all discussions about corporate executive pay, and it ends with the directors looking guilty as charged. Like all mysteries, it begins with the discovery of the crime: suboptimal pay practices, pay without performance, runaway executive compensation, and growing inequality. However, in modern corporate governance discussions, the butler always did it. All modern observers have done to determine guilt in a given case is apply agency cost theory to the problem and the answer becomes clear: managers are self-dealing and boards are too weak or conflicted to stop them. Convicted, boards of directors are incarcerated in a cage of increasingly dense restrictions imposed by 
legislatures, regulators, stock exchanges, tribunes of good governance, proxy advisors, and shareholders.

It is impossible to overstate the importance of the agency cost explanation for failures in executive compensation practices. Executive compensation, which has exploded in the past three decades, is the best evidence for the thesis that underlies the entire modern corporate governance regime: that directors, left to their own devices, are incapable of reliably standing up to rapaciously self-interested executives. ${ }^{1}$ But what if this wasn't true? What if, instead of using agency cost assumptions to go directly from the crime to the sentencing, the evidence was consulted and the directors exonerated? What if, in the kind of twist beloved by mystery fans, the very forces of good governance making the accusations and providing the remedies are the guilty parties? A great deal of modern corporate governance would have to be rethought.

\section{The Role of Executive Compensation IN CURRENT DiscuSSIONS OF CORPORATE GOVERNANCE}

The explosive growth in executive compensation is a surprisingly modern phenomenon. ${ }^{2}$ Median chief executive officer (CEO) pay in the United States stayed constant, around \$1 million a year, between the 1940s and 1970s. ${ }^{3}$ It began to rise through the 1970 s at a modest increase of about 20 percent over the course of the decade. ${ }^{4}$ It then rose by 50 percent during the 1980 s and by a further 128 percent during the $1990 \mathrm{~s} .{ }^{5}$ The financial turmoil of the past decade, with its two recessions, complicates the picture, with compensation increasing only slightly over the period, although it appears to be growing quickly again coming out of the recession. ${ }^{6}$ In any event, the broad trend can be stated simply: between 1978 and 2012, average CEO pay of the 350 largest US companies increased by 875 percent. $^{7}$ For

See e.g. Ruth Bender \& Lance Moir, "Does 'Best Practice' in Setting Executive Pay in the UK Encourage 'Good' Behaviour?" (2006) 67:1 J Business Ethics 75 ("'t t]he literature on executive pay ... mostly focuses on pay as an agency issue" at 76). See also the sources discussed at notes 20-22, below. This paragraph and the one following, along with their accompanying citations, were taken from a companion article: Bryce C Tingle, "How Good Are Our 'Best Practices' When It Comes to Executive Compensation? A Review of Forty Years of Skyrocketing Pay, Regulation and Corporate Governance" [forthcoming] [Tingle, "How Good?"]. Carola Frydman \& Dirk Jenter, "CEO Compensation" (2010) 2 Annual Rev Financial Economics 75 at 78-80, Table 1 , graphs a \& b.

Ibid at 80 .

Ibid.

Thomas Piketty \& Emmanuel Saez, "Top Incomes and the Great Recession: Recent Evolutions and Policy Implications” (2013) 61:3 IMF Economic Rev 456 at 458.

Lawrence Mishel \& Natalie Sabadish, "CEO Pay in 2012 Was Extraordinarily High Relative to Typical Workers and Other High Earners" (2013) 367 Economic Policy Institute 1 at 4, online: <www.epi.org/ files/2013/ceo-pay-2012-extraordinarily-high.pdf>. See also Lucian Bebchuk \& Yaniv Grinstein, "The Growth of Executive Pay" (2005) 21:2 Oxford Rev Economic Policy 283 at 286-87 [Bebchuk \& Grinstein, "Growth of Executive Pay"]; Harwell Wells, "U.S. Executive Compensation in Historical Perspective" in Randall S Thomas \& Jennifer G Hill, eds, Research Handbook on Executive Pay (Northampton, MA: Edward Elgar, 2012) 41 at 49; Martin J Conyon, "Executive Compensation and Board Governance in US Firms" (2014) 124 Economic J F60 [Conyon, "Executive Compensation"] (the trend in pay reflects "a real growth rate ... of approximately $4 \%$ per annum every year for almost 30 years" at F60); Joseph E Stiglitz, The Price of Inequality (New York: WW Norton \& Company, 2012) at $25-27$. 
perspective, the average wage of non-management employees rose only 5.7 percent. ${ }^{8}$ By the end of the period, the ratio of CEO pay to worker pay rose by about 900 percent from $29: 1$ in 1978 to $273: 1$ in $2012 .^{9}$

The growth in CEO compensation has also outstripped the returns of shareholders: CEO pay growth has doubled the rise of the S\&P Index over the past 30 years. ${ }^{10}$ In 1993 , midway through the growth period, payments to the five highest-paid senior executives in a given US company absorbed, on average, 5 percent of its profits; by 2003, this had increased to 10 percent. $^{11}$

\section{A. The Agency Cost Explanation}

This phenomenal increase in pay has not gone unobserved. One of the leading scholars in the area has noted that the number of articles written on executive pay may have grown faster than executive pay itself. ${ }^{12}$ Another scholar simply refers to the phenomenon as having spawned "an awful lot of academic studies." 13 The principal reason for this academic interest is that executive pay goes to the heart of corporate governance. The modern conception of corporate governance arose out of a change in focus from maximizing external cash flows to regulating corporate internal cash flows. ${ }^{14}$ Executive pay is the most direct — and visible - feature of these internal cash flows. Nothing seems to be a better barometer of managerial power, director conscientiousness, shareholder oversight, or the strength of fiduciary duties, than how much of the internal cash earned by a company is diverted to its senior management. The result, as David Larcker at Stanford observes, is that "[e]xecutive compensation is perhaps the most contentious issue in corporate governance today." 15 Lord Kay in his well known 2012 report on United Kingdom equity markets related that, "[s]ince the Review was established [in the wake of the 2008 financial crisis], executive remuneration

$8 \quad$ Marc Moore, "Corporate Governance, Pay Equity, and the Limitations of Agency Theory" (2015) University of Cambridge Faculty of Law Working Paper No 8/2015 at 7, online: $<$ https://papers.ssrn. $\mathrm{com} / \mathrm{sol} /$ papers.cfm?abstract id=2566314>.

Ibid; Alex Edmans \& Xavier Gabaix, "Executive Compensation: A Modern Primer" (2015) National Bureau of Economic Research Working Paper No 21131, online: <www.nber.org/papers/w21131> (in 2013, "CEO pay was 350 times that of the average worker" at 4). See also Kevin J Murphy, "Executive Compensation," in Orley C Ashenfelter \& David Card, eds, Handbook of Labor Economics, vol 3B (Amdsterdam: Elsevier, 1999) [Murphy, "Executive Compensation"]. In Canada, statistics are hard to come by prior to 1995, but in 1998 the average CEO of the 100 largest companies in Canada earned 105 times more than the average Canadian; in 2013 he or she earned 195 times more. The top 50 CEOs earned 269.7 times more than the average Canadian: see Hugh Mackenzie, "Glory Days: CEO Pay in Canada Soaring to Pre-Recession Highs" Canadian Centre for Policy Alternatives (January 2015) at 7-8, online: $<$ https://www.policyalternatives.ca/publications/reports/glory-days $>$.

$10 \quad$ Mishel \& Sabadish, supra note 7 at 4; Steven N Kaplan, “Are U.S. CEOs Overpaid?" (2008) 22:2 Academy Management Perspectives 5 at 8-10, Figures 1-4 (between 1993 and 2006, US CEO compensation increased from approximately 100 times the median household income in 1993 to more than 200 times the median household income in 2006). See also Carola Frydman \& Raven E Saks, "Executive Compensation: A New View from a Long-Term Perspective, 1936-2005" (2010) 23:5 Rev Financial Studies 2099 at 2111, Figure 3.

Bebchuk \& Grinstein, "Growth of Executive Pay," supra note 7 at 302.

Murphy, "Executive Compensation," supra note 9 at 2486.

Conyon, "Executive Compensation," supra note 7 at F60.

For a history of this transition, see Bryce C Tingle, "What Do We Really Know About Corporate Governance Best Practices? A Review of the Empirical Research Since 2000" [forthcoming] [Tingle, "Corporate Governance"].

15 David F Larcker \& Brian Tayan, "Seven Myths of Executive Compensation” (2011) Rock Center for Corporate Governance at Stanford University Working Paper No CGRP-17 at 1, online: $<\mathrm{https}: / / \mathrm{ssrn}$. com/abstract $=1869019>$. 
has attracted more controversy and public attention than any other issue related to equity markets." 16

Since the publication of Michael Jensen and William Meckling's "Theory of the Firm: Managerial Behavior, Agency Costs and Ownership Structure” in 1976, which began the modern era of corporate governance theory, executive pay practices have been seen primarily as instantiations of a particular version of agency cost theory. ${ }^{17}$ At its narrowest, any pay given to an executive is an agency cost, as it is an expense attached to employing an agent. But the controversy around executive pay that characterizes current discussions is predicated on a broader thesis: that the agents are being overpaid. According to this thesis, these agents have developed the power to set their own pay in defiance to the wishes and best interest of their principals, and are aided by negligence or conflicts on the part of directors who should be preventing precisely this sort of self-dealing. In this article, I will refer to this theory as the "agency cost" or "governance-failure" theory of executive pay.

Jensen himself advanced the governance-failure theory of executive remuneration in the decades following the publication of "Theory of the Firm," and he was not alone. ${ }^{18}$ For example, the Nobel prize-winning economist, Eugene Fama, pointed out in 1980 that, "[h]aving gained control of the board, top management may decide that collusion and expropriation of security holder wealth are better than competition among themselves."19 Once again, statements of this sort are not the modest (and unexceptional) claims that agency costs of different types arise in the context of remuneration arrangements. Instead, they are an articulation of the now widespread assumption that corporate remuneration arrangements can only be understood as economically inefficient rent extraction underwritten by failures at the board level to constrain senior managers. This is not advanced as an explanation for certain isolated examples, but as a feature of the remuneration process generally. The agency cost explanation for executive remuneration thus constitutes a broad indictment of the traditional roles of directors and officers in business corporations.

16 UK, Department for Business, Innovation \& Skills, The Kay Review of UK Equity Markets and LongTerm Decision Making: Final Report by John Kay (London: Department for Business, Innovation \& Skills, 2012) at 77 [Kay Report]. See also US, Financial Crisis Inquiry Commission, The Financial Crisis Inquiry Report: Final Report of the National Commission on the Causes of the Financial and Economic Crisis in the United States (Washington, DC: US Government Printing Office, 2011).

17 Michael C Jensen \& William H Meckling, "Theory of the Firm: Managerial Behavior, Agency Costs and Ownership Structure" (1976) 3:4 J Financial Economics 305 (a CEO, as a utility maximizer, will not always act in the best interests of the shareholders and principals generally, including in the context of remuneration); Michael C Jensen \& Kevin J Murphy, "Remuneration: Where We've Been, How We Got to Here, What Are the Problems, and How to Fix Them" (2004) European Corporate Governance Institute Working Paper No 44/2004 [Jensen \& Murphy, "Remuneration Fix"](“[w]hile remuneration can be a solution to agency problems, it can also be a source of agency problems" at 50). See also Patrice Gélinas \& Lisa Baillargeon, "CEO Compensation in Canada, 1971-2008” (2013) 8:12 Intl J Business Management 1 ("[t]he modern history of executive compensation began in parallel with the emergence and acceptance of agency theory" at 1); Conyon, "Executive Compensation," supra note 7 ("[t]he standard theoretical approach to executive compensation is the principal-agent model" at F63); Dan R Dalton et al, "The Fundamental Agency Problem and Its Mitigation" (2007) 1:1 Academy Management Annals 1, DOI: $<10.1080 / 078559806>$ (discussing the use of equity incentives as a method of mitigating agency costs).

18 Jensen \& Murphy, "Remuneration Fix," ibid ("many notorious excesses in pay can be traced to poor governance" at 22). See also Michael C Jensen, "The Modern Industrial Revolution, Exit, and the Failure of Internal Control Systems" (1993) 48:3 J Finance 831 at 870-71.

19 Eugene F Fama, "Agency Problems and the Theory of the Firm" (1980) 88:2 J Political Economy 288 at 293. 
The agency cost explanation of executive compensation grew in prominence in law review and finance articles in the 1980s and 1990s. ${ }^{20}$ As Jensen and Kevin Murphy articulated it in the wake of the Enron-era scandals: "Because managers are self interested and because remuneration committee members are spending the firm's resources, not their own, there is major potential for the participants in the system to behave in ways that will exacerbate, not reduce, agency problems." 21 Further, the authors went on to explain that "bad governance can easily lead to value-destroying pay practices, and many notorious excesses in pay can be traced to poor governance." 22

Today's most prominent exponents of the governance-failure school of executive remuneration are Harvard law professors Lucian Bebchuk and Jesse Fried, who argue in a series of articles ${ }^{23}$ and in their 2004 book, Pay Without Performance: The Unfulfilled Promise of Executive Compensation, that managers set their own pay, often disguising it from their principals, the shareholders, supported by quiescent and compromised boards of directors. $^{24}$

Outside of the academy, the governance-failure explanation for corporate pay practices is simply assumed by the constellation of parties that make up what can be termed the "governance industry." 25 This is the collection of think tanks, proxy advisors, advocacy organizations, institutional investors, consultants, media outlets, and regulators that concern themselves with corporate governance. ${ }^{26}$ Because they don't have the resources or incentives to engage in the investigation of individual company governance (they must generate reports,

See e.g. ibid; Bengt Holmström, "Managerial Incentive Problems: A Dynamic Perspective" (1999) 66:1 Rev Economic Studies 169; Bengt Holmström, "Moral Hazard and Observability" (1979) 10:1 Bell J Economics 74 at 74 (discussing principal-agent information asymmetry in the context of labour contracting); Charles M Elson, "Executive Overcompensation - A Board-Based Solution" (1993) 34:5 Boston College L Rev 937 at 942 (warning that when it comes to executive compensation, boards have been captured by management); Derek Bok, The Cost of Talent: How Executives and Professionals Are Paid and How It Affects America (New York: Free Press, 1993) at 98 (executives set their own pay and directors have too little information and incentives to properly regulate this process); Eugene $\mathrm{F}$ Fama \& Michael C Jensen, "Separation of Ownership and Control" (1983) 26:2 JL \& Econ 301 (examining the use of pay by boards to mitigate agency costs); Graef S Crystal, In Search of Excess: The Overcompensation of American Executives (New York: WW Norton \& Company, 1991) at 221-23 (discusses the system of self-dealing that produced US corporate remuneration practices); Jensen \& Murphy, "Remuneration Fix," supra note 17 at 82 (the structure of executive compensation particularly pay-for-performance - is important in mitigating agency costs); Sanford J Grossman \& Oliver D Hart, “An Analysis of the Principal-Agent Problem" (1983) 51:1 Econometrica 7 (discussing optimal incentive schemes to mitigate agency costs).

21 Jensen \& Murphy, "Remuneration Fix," ibid at 22.

Ibid.

Lucian Arye Bebchuk, Jesse M Fried \& David I Walker, "Managerial Power and Rent Extraction in the Design of Executive Compensation" (2002) 69:3 U Chicago L Rev 751 at 784-86; Lucian Arye Bebchuk \& Jesse M Fried, "Executive Compensation as an Agency Problem" (2003) 17:3 J Economic Perspectives 71 at 77 [Bebchuk \& Fried, "Agency Problem"].

24 Lucian Bebchuk \& Jesse Fried, Pay Without Performance: The Unfulfilled Promise of Executive Compensation (Cambridge, MA: Harvard University Press, 2004) at 62-63 [Bebchuk \& Fried, Pay Without Performance]. See also Lucian Arye Bebchuk \& Jesse M Fried, "Stealth Compensation via Retirement Benefits" (2004) 1:2 Berkeley Business LJ 291 at 296.

25 See Tingle, "Corporate Governance," supra note 14.

26 Suzanne Stevens, "Inside the Corporate Governance Complex" (20 May 2010) Harvard Law School Forum on Corporate Governance and Financial Regulation (blog), online: <https://corpgov.law. harvard.edu/inside-the-corporate-governance-complex/> (describing the corporate governance industry as a "well-funded, sprawling and interlocking set of institutions that have grown up around corporate governance over the past 30 years or so ... with major outposts across the country at research universities, law firms, the federal government, institutions, activist hedge funds and even blogs like this one, [which generates] considerable intellectual and financial firepower" at para 1). 
rankings, or standardized advice for a wide spectrum of firms), the governance industry relies on various governance best practices or rules of thumb. ${ }^{27}$

The largest proxy advisory firm, Institutional Shareholder Services (ISS), prefaces their 2015 FAQ on executive compensation by describing the losses experienced by shareholders following the financial crisis and contrasting it to the rapid increase of executive remuneration, which surpasses pre-crisis levels in many Canadian companies. ISS notes that "[e]xecutive compensation practices and their link to company performance and shareholder value continues to remain the number one concern of investors, generally some twenty-five years since these concerns were first raised." 28 The assumption that directors are not to be trusted in their role in setting executive compensation explains many ISS voting outcomes: support for say-on-pay shareholder proposals, ${ }^{29}$ voting against directors if certain compensation arrangements are entered into, ${ }^{30}$ requiring compensation committees comprised only of independent directors, ${ }^{31}$ requiring communication with, and responsiveness to, the company's shareholders on remuneration matters, ${ }^{32}$ and, most of all, ISS' own set of best practices for executive remuneration and punishing board-approved deviations. ${ }^{33}$ All of these voting outcomes are driven by the assumption that managerial control over executive compensation is either a fact, or always and everywhere an imminent threat, and that boards cannot be trusted to adequately address this state of affairs.

Advocacy organizations such as the Canadian Coalition for Good Governance (CCGG) make similar assumptions throughout their recommendations for "high performance" boards. ${ }^{34}$ These include the usual strictures for boards to distance themselves from managers when approving executive compensation (by, for example, forming a compensation committee, permitting only independent directors to serve on the committee, restricting CEOs of other companies from sitting on the committee, and not including management in meetings when compensation is deliberated) along with instructions to align managerial pay with shareholder returns, and, just like ISS, replacing board discretion over pay structure with adherence to CCGG's own "Executive Compensation Principles." "35

Organizations such as the Shareholder Association for Research \& Education (SHARE) and the Ontario Securities Commission's (OSC) Investor Advisory Panel support measures such as say-on-pay and enhanced disclosure around remuneration (as well as the other usual governance best practices) on the basis that "[b]oards of directors and compensation

Bryce C Tingle, "Bad Company! The Assumptions behind Proxy Advisors' Voting Recommendations" (2014) 37:2 Dal LJ 709 at 740 [Tingle, "Proxy Advisors"]; Tingle, "Corporate Governance," supra note 14.

Institutional Shareholder Services, "Canada Executive Compensation: Frequently Asked Questions" (22 December 2014) at 5, online: <https://www.issgovernance.com/file/policy/2015faqcanadaexecutive compensation.pdf $>$ [ISS, "2015 FAQ"].

29 Institutional Shareholder Services, "Canada Proxy Voting Guidelines for TSX-Listed Companies: 2015 Benchmark Policy Recommendations"(22 December 2014) at 41, online: $<$ https://www.issgovernance. com/file/policy/2015canadatsxvotingguidelines.pdf $>$.

Ibid at $32-33$.

Ibid at 9 .

Ibid at 34 .

Ibid at $28-33$.

See e.g. Canadian Coalition for Good Governance, "Building High Performance Boards" (August 2013), online: <www.ccgg.ca/index.cfm?id=17595> [CCGG, "High Performance Boards"].

Ibid at 14-21; Canadian Coalition for Good Governance, "Executive Compensation Principles" (January 2013), online: <www.ccgg.ca/index.cfm?id=17579> [CCGG, "Executive Compensation”]. 
committees in particular have been accused over the years of being complacent, unqualified and beholden to management as directors shared in many lucrative compensation schemes along with company executives." 36

Think tanks in Canada working in the area of corporate governance, such as the Centre for Policy Alternatives, argue that pay levels in this country can only be explained by the fact that "boards of directors are often totally dependent on the CEO they hire" and that say-onpay is not helpful because the shareholder vote is not binding on directors. ${ }^{37}$ The Institute for Governance of Private and Public Organizations (IGPPO) summarizes the common view of investors that, "boards of directors too often failed in their explicit duty to protect shareholders' interest against expropriation of their wealth by management ... [ $t$ ] hey did not provide the checks, the safeguards, and the 'push back' on management that were assumed by investors." ${ }^{\prime 3}$ This is reminiscent of legendary investor Warren Buffet's famous 2004 remark that " $[\mathrm{t}]$ he typical large company has a compensation committee. They don't look for Dobermans on that committee, they look for Chihuahuas - Chihuahuas that have been sedated." ${ }^{39}$

The logical consequence of the agency cost explanation of executive compensation failures is further regulation. A recent summary of the finance literature on executive compensation described the process: "This perspective [governance-failure explanations], espoused most prominently by Bebchuck and Fried (2004), has been taken very seriously by both scholars and policymakers, and led to major regulatory changes. $" 40$ In the US these included changes to the tax rules in 1993 to discourage any pay not linked to performance, ${ }^{41}$ increased disclosure of compensation in the $1990 \mathrm{~s}$ and, most recently, in $2006,{ }^{42}$ the Sarbanes-Oxley prohibitions on personal loans, mandated clawback provisions and enhanced option disclosure, ${ }^{43}$ say-on-pay requirements in Dodd-Frank in $2010,{ }^{44}$ requirements to provide disclosure on compensation consultants, ${ }^{45}$ caps on executive remuneration in

Letter from Institutional Shareholder Services to Ontario Securities Commission (31 March 2011) Re: OSC Staff Notice 54-701 — Regulatory Developments Regarding Shareholder Democracy Issues at 3, online: $<$ www.osc.gov.on.ca/documents/en/Securities-Category5-Comments/com_20110331_54-701 sistid.pdf $>$, quoted approvingly in Letter from OSC Investor Advisory Panel to Ontario Securities Commission (18 April 2011) Re: OSC Staff Notice 54-701 at 4, online: <www.osc.gov.on.ca/docu ments/en/Securities-Category5-Comments/com_20110418_54-701_ananda.pdf $>$. See also Shareholder Association for Research \& Education, "It's Time for Canadian Securities Regulators to Complete the Say on Pay Picture" (15 June 2016), online: $<$ www.share.ca/its-time-for-canadian-securities-regulatorsto-complete-the-say-on-pay-picture > (advocating say-on-pay be adopted by all Canadian companies so as to foster shareholder input into remuneration decisions and encourage better disclosure to shareholders about pay-for-performance features).

$37 \quad$ Mackenzie, supra note 9 at 16.

38 Yvan Allaire, "Pay for Value: Cutting the Gordian Knot of Executive Compensation" (2012) at 42, online: Institute for Governance of Private and Public Organizations <www.igopp.org/wpcontent/uploads/2014/04/pp_payforvalue_allaire_en_v4.pdf $>$. Quoted in Conyon, "Executive Compensation," supra note 7 at F61.

Edmans \& Gabaix, supra note 9 at 2.

Steven Balsam, "Taxes and Executive Compensation" (2012) Economic Policy Institute Briefing Paper No 344 at 3, online: <www.epi.org/publication/taxes-executive-compensation/>.

42 Martin J Conyon et al, "The Executive Compensation Controversy: A Transatlantic Analysis" (2011) Cornell University ILR School Working Paper No 2011-002 at 9, online: Institute for Compensation Studies <www.digitalcommons.ilr.cornell.edu/ics/5> [Conyon et al, "Compensation Controversy"].

43 Sarbanes-Oxley Act, 15 USC $\S \S 304,402-403$ (2002).

44 Dodd-Frank Wall Street Reform and Consumer Protection Act, 12 USC $\$ 951$ (2010) [Dodd-Frank Act]. Ibid, $\S 952$. 
government-assisted firms in 2008, ${ }^{46}$ and Securities and Exchange Commission (SEC) rules in 2013 requiring firms to disclose the ratio of CEO pay to median employee pay. ${ }^{47}$

In the UK, the regulation of executive compensation has included increasing disclosure requirements (such as those found in the Directors' Remuneration Report Regulations), ${ }^{48}$ establishing say-on-pay advisory votes in $2002,{ }^{49}$ articulating various best practices in the 2003 UK Combined Code on Corporate Governance, ${ }^{50}$ amending UK company law to make some say-on-pay votes mandatory on boards, ${ }^{51}$ imposing personal liability on directors who proceed with unauthorized pay schemes, ${ }^{52}$ providing shareholders with a vote on compensation policies every three years, ${ }^{53}$ and requiring institutional shareholders to become more involved in executive pay decisions (as seen from the UK Financial Reporting Council)..$^{54}$

In contrast to its largest economic partners, Canada has avoided major regulatory interference with corporate remuneration decisions. The Toronto Stock Exchange (TSX) has, over time, increased the range of compensation matters on which the shareholders must be provided a vote, ${ }^{55}$ and the federal government has created tax rules to encourage the use of stock options. ${ }^{56}$ Canadian securities regulators have increased and refined disclosure requirements relating to compensation in $1993,2003,{ }^{57} 2007,{ }^{58} 2008,{ }^{59} 2011,{ }^{60}$ and $2015 .{ }^{61}$

46 US, Department of the Treasury, "TARP Standards for Compensation and Corporate Governance" (2009) at 9-10, online: Executive Compensation Rules \& Guidance <www.treasury.gov/initiatives/ financial-stability/TARP-Programs/executive-comp $>$.

47 Dodd-Frank Act, supra note 44, § 953(b).

48 The Large and Medium-sized Companies and Groups (Accounts and Reports) (Amendment) Regulations, SI 2013/1981.

49 The Directors' Remuneration Report Regulations 2002, SI 2002/1986, s 7 (now replaced by The Large and Medium-sized Companies and Groups (Accounts and Report) Regulations 2008, SI 2008/410.

50 Financial Reporting Council, "The Combined Code on Corporate Governance"(2003), online: European Corporate Governance Institute <www.ecgi.org/codes/code.php?code_id=119>. This Code contains good corporate governance principles applicable to public listed companies, but has since been replaced by Financial Reporting Council, "The UK Corporate Governance Code" (September 2014) online: $<$ https://www.frc.org.uk/Our-Work/Codes-Standards/Corporate-Governance/UK-CorporateGovernance-Code.aspx $>$.

$51 \quad$ Enterprise and Regulatory Reform Act 2013 (UK), c 24, s 79.

Ibid, s 80(226E).

Ibid, s 79(439A).

Financial Reporting Council, "The UK Stewardship Code” (September 2012), online: $<$ https://www.frc. org.uk/Our-Work/Codes-Standards/Corporate-governance/UK-Stewardship-Code.aspx>.

55 See Sean Bernstein \& Andrew MacDougall, "Say On Pay 2014: Losing Steam in Canada" (2014) at 3, online: Osler, Hoskin \& Harcourt LLP < https://www.osler.com/en/resources/governance/2014/proxy/ say-on-pay-2014-losing-steam-in-canada $>$ (say-on-pay in Canada is not mandatory).

$56 \quad$ Income Tax Act, RSC 1985, c 1 (5th Supp), s $110(1)(\mathrm{d})$.

57 Notice of Commission Approval of National Instrument 51-102 Continuous Disclosure Obligations, Companion Policy 51-102CP, Rule 51-801 Implementing National Instrument 51-102 Continuous Disclosure Obligations and Companion Policy 51-801CP and Related Instruments, OSC Notice 1.1.8, (2003) 26 OSCB 8150 (19 December 2003), online: <www.osc.gov.on.ca/documents/en/SecuritiesCategory5/rule_20031219_51-102-51-801_approv.pdf $>$.

58 National Instrument 51-102 Continuous Disclosure Obligations, OSC Notice, (2006) 29 OSCB (Supp-2) (13 October 2006) at 55-58, online: <www.osc.gov.on.ca/documents/en/Securities-Category5/rule 20061013_51-102_supplement.pdf $>$.

59 Notice Form 51-102F6 Statement of Executive Compensation, CSA Notice (18 September 2008).

60 Amendments to Form 51-102F6 Statement of Executive Compensation and Consequential Amendments, OSC CSA Notice, (2011) 34 OSCB 8047 (22 July 2011), online: <www.osc.gov.on.ca/en/Securities Law_20110722_51-102-f6_amd-exec-comp.htm>.

61 Amendments to National Instrument 51-102 Continuous Disclosure Obligations, (2015) 38 OSCB 5121 (4 June 2015) at 5125-34 (creating a new form to report the executive compensation of venture issuers), online: <http://www.osc.gov.on.ca/en/SecuritiesLaw_ni_20150604_51-102_amd-disclosure-obligations .htm>. 
This does not include the securities commissions' publication of FAQs, issuer audit results, and other forms of suasion and guidance. ${ }^{62}$ When the OSC invited submissions on the merits of bringing say-on-pay to Canada, all of the letters sent in support of the move referenced explicitly or implicitly the governance-failure version of how remuneration is set in companies. $^{63}$

In all three countries, however, the governance-failure explanation for executive pay is most powerful outside the regulatory sphere as a ready-made rationale for increased shareholder influence over companies (alleged remuneration failures are usually a feature of activist shareholder proxy campaigns), ${ }^{64}$ increased power of third party proxy advisors,${ }^{65}$ and greater importance of the advice, rankings, and proposed retention of various members of the corporate governance industry. ${ }^{66}$ But is the explanation true?

\section{EMPirical EVIDENCE About Certain Executive Pay Practices}

The actual pay practices that have produced the modern rise in executive compensation are well understood. ${ }^{67}$ During the period of the most rapid rise in corporate pay, 1992-2008,

62 See e.g. 51-304 Report on Staff's Review of Executive Compensation Disclosure, BCSC CSA Staff Notice (30 October 2002); Report on Staff's Review of Executive Compensation Disclosure, CSA Staff Notice 51-331, (2009) 32 OSCB 9599 (20 November 2009).

63 See the following letters in response to the Request for Comments published by Ontario Securities Commission Staff Notice 54-701 on whether regulatory reform to securities legislation is required to address shareholder democracy issues: Letter from OSC Investor Advisory Panel to Ontario Securities Commission (18 April 2011), online: <www.osc.gov.on.ca/documents/en/Securities-Category5Comments/com_20110418_54-701_ananda.pdf>; Letter from Astral Media Inc to Ontario Securities Commission (29 March 2011) online: <www.osc.gov.on.ca/documents/en/Securities-Category5Comments/com 20110329 54-701 catellierb.pdf $>$; Letter from Broadridge Financial Solutions Inc to Ontario Securities Commission (31 March 2011), online:<www.osc.gov.on.ca/documents/en/SecuritiesCategory5-Comments/com 20110331 54-701 roschp.pdf $>$; Letter from Canadian Coalition for Good Governance to Ontario Securities Commission (31 March 2011), online: <www.ccgg.ca/site/ ccgg/assets/pdf/CCGG Response to OSC Staff Notice 54-701.pdf>; Letter from Emerson Advisory to Ontario Securities Commission (23 March 2011), online: <www.osc.gov.on.ca/documents/en/ Securities-Category5-Comments/com_20110323_54-701_emersonh.pdf $>$; Letter from Institute of Corporate Directors to Ontario Securities Commission (28 March 2011) online: <www.osc.gov.on.ca/ documents/en/Securities-Category5-Comments/com_20110328_54-701_magidsons.pdf $>$; Letter from NEI Investments to Ontario Securities Commission (30 March 2011), online: <https://www.nei investments.com/documents/PublicPolicyAndStandards/2011/OSC\%20Shareholder \%20Democracy.pdf $>$; Letter from Pension Investment Association of Canada to Ontario Securities Commission (31 March 2011), online: < https://www.piacweb.org/files/OSC-re-Staff-Notice-54-701Mar-31-11.pdf>; Letter from signatories to the United Nations-backed Principles for Responsible Investment to Ontario Securities Commission (31 March 2011), online: NEI Investments $<$ https://www. neiinvestments.com/documents/PublicPolicyAndStandards/2011/UNPRI\%20 Signatory\%20submission\%20to\%20OSC_Staff\%20Notice\%2054-701.pdf $>$.

64 Yonca Ertimur, Fabrizio Ferri \& Volkan Muslu, "Shareholder Activism and CEO Pay" (2011) 24:2 Rev Financial Studies 535 at 574 [Ertimur, Ferri \& Muslu, "Shareholder Activism"]. For the uses of executive pay in recent activist campaigns involving Shutterfly Inc., Qualcomm Inc., DuPont Co., and Perry Ellis International Inc., see Liz Hoffman, "Activist Funds Put Executive Pay Formulas Under Microscope," The Wall Street Journal (11 June 2015), online: <www.wsj.com/articles/activist-fundsput-executive-pay-formulas-under-microscope-1434058799>.

65 See e.g. George W Dent Jr, "A Defense of Proxy Advisors" (2014) Michigan State L Rev 1287 at 1298-307 (makes a case for third party proxy advisors and concludes that regulation of these firms is unwarranted in part because of executive pay issues at companies); Institutional Shareholder Services, "Executive Summary Proxy Voting Guideline Updates and Process: 2016 Global Benchmark Policy Updates" (20 November 2015) at 3-5, online: <https://www.issgovernance.com/file/policy/executivesummary -of-key-2016-updates-and-policy.pdf $>$ (describing the utility of ISS' engagement with its institutional customers, with emphasis on executive pay practices).

66 Dent, ibid at 1295 .

67 The remainder of this paragraph and its accompanying citations were taken from Tingle, "How Good?," supra note 2 . 
median CEO salaries only grew from $\$ 0.8$ million to $\$ 0.9$ million and straightforward cash bonuses from $\$ 0.6$ million to $\$ 1$ million. ${ }^{68}$ Nearly all the growth in total pay came from increasing equity incentives such as share grants and stock options. ${ }^{69}$ From the 1940 s to the 1980 s, regular salary and bonuses accounted for 99 percent to 74 percent of CEO pay, but declined to approximately 40 percent by the middle of the last decade. ${ }^{70}$ By 2010,62 percent of the compensation received by American large company CEOs came from equity incentives alone. $^{71}$

The growth in the use of equity as part of executive pay was primarily due to the adoption of two remuneration practices over the relevant time period: deploying equity grants (especially stock options) to align the interests of executives and shareholders, and adopting pay-for-performance schemes (which can use cash, but tend to use equity grants as awards). ${ }^{72}$ My companion article investigates the merits of these two best practices in depth, but only a summary of its conclusions can be provided here.

The first of the two new remuneration practices to be widely adopted was the proliferation of equity-based compensation plans in the 1980s and 1990s ${ }^{73}$ Equity grants were one of agency theory's most obvious implications for corporate governance: agents would fulfill their responsibilities more conscientiously if they shared in the rewards accruing to their principals, the shareholders. ${ }^{74}$ It was not originally intended that equity awards closely reflect the actual contributions of executives to increases in corporate value, which is the rationale for pay-for-performance schemes. Rather, giving equity stakes to executives was designed to ensure they made decisions that were in the best interests of equity holders. ${ }^{75}$ The classic case at the time was encouraging US executives to facilitate takeovers that would deprive the executives of their employment and associated perquisites. Generous equity holdings would,

Frydman \& Jenter, supra note 3 at 81. See also Lucian A Bebchuk \& Jesse M Fried, "Pay Without Performance: Overview of the Issues" (2005) 17:4 J Applied Corporate Finance 8 at 16-18; Gian Luca Clementi \& Thomas F Cooley, "Executive Compensation: Facts" (2009) National Bureau of Economic Research Working Paper No 15426 at 2, online: <www.nber.org/papers/w15426.pdf>. Brian J Hall \& Jeffrey B Liebman, “Are CEOs Really Paid Like Bureaucrats?” (1998) 113:3 QJ Economics 653 at 662; Frydman \& Saks, supra note 10 at 2106-109.

70 Allaire, supra note 38 at 19 , Figure 4.

71 Ibid at 24, Figure 8 (this is for American companies). See also Conyon, "Executive Compensation," supra note 7 at F74 (in 2012, grants of stock options and restricted stock accounted for almost half of total CEO pay for S\&P 500 companies).

Tingle, "How Good?," supra note 2, nn 40, 42, 57, 114, 118.

For a detailed history, see ibid, nn 58-60.

Jensen \& Meckling, supra note 17 (referring to "the fraction of the equity held by the manager" as basic to the agency problem at 53); Brian J Hall, "What You Need to Know About Stock Options" (2000) 78:2 Harvard Business Rev 121 at 122 [Hall, "Stock Options"]; Stephen Bryan, LeeSeok Hwang \& Steven Lilien, "CEO Stock-Based Compensation: An Empirical Analysis of Incentive-Intensity, Relative Mix, and Economic Determinants" (2000) 73:4 J Business 661 at 665 (shareholders view pay-forperformance compensation as means of encouraging the CEO to exploit available investment opportunities so as to create wealth); Kay Report, supra note 16 ("[s] hare options were perceived as a means of aligning the interests of managers and shareholders" at 77).

Charles P Himmelberg, R Glenn Hubbard \& Darius Palia, "Understanding the Determinants of Managerial Ownership and the Link Between Ownership and Performance" (1999) 53 J Financial Economics 353 at 354 (a potential solution to the fundamental agency problem is to provide managers with equity stakes in their firms, as this aligns the interests of managers and shareholders, causing firm performance to improve as managers concurrently work for their own and shareholders' benefit). 
it was thought, provide proper incentives for executives to take actions that were good for shareholders but adverse to the executives' personal interests as employees. ${ }^{76}$

From the beginning, many finance scholars pointed out that, however reasonable the arguments in favour of equity incentives might seem, there was little empirical evidence they actually worked to do anything but enrich executives. ${ }^{77}$ Scholarly warnings about the paucity of evidence supporting equity incentives continued throughout the next two decades ${ }^{78}$ even as companies universally adopted them and governments designed tax schemes intended to promote them. $^{79}$

Over time, a critical mass of research developed showing that executives' equity exposure had no impact on any real measure of corporate performance. ${ }^{80}$ Two meta-analyses of the research in 2003 and 2007, reviewing over 250 empirical studies in aggregate, found equity incentives contributed nothing to corporate performance. ${ }^{81}$ There was some evidence that equity grants produced management techniques designed to increase earnings without changing firm performance (for example through the use of increased leverage) and that investors appear to widely expect equity plans to improve performance, but as the 2007 meta-study concluded, "[t]his result is not confirmed by the real accounting returns."

Marcel Kahan \& Edward B Rock, "How I Learned to Stop Worrying and Love the Pill: Adaptive Responses to Takeover Law" (2002) 69:3 U Chicago L Rev 871 at 896-97 (equity pay helped make takeovers more palatable to executives, reducing the adverse impact of the poison pill's immunization of management teams from the market for corporate control). This is just one of many problems with long term vesting requirements for equity pay schemes. See also Volker Laux, "Stock Option Vesting Conditions, CEO Turnover, and Myopic Investment" (2012) 106 J Financial Economics 513 at 521-22 (discussing the advantages to a CEO of strategic behaviour to avoid risk of dismissal until equity is vested); Neil Brisley, "Executive Stock Options: Early Exercise Provisions and Risk-Taking Incentives" (2006) 61:5 J Finance 2487 at 2488 (much of an executive's net worth tied up in unvested equity causes her to turn down potentially value-creating projects that carry risk).

James L Bothwell, "Profitability, Risk, and the Separation of Ownership from Control" (1980) 28:3 J Industrial Economics 303 (observing that, in 1980, the evidence concerning the relationship of executive equity holdings to firm performance was "quite mixed" at 304).

78 See e.g. Herbert G Hunt, "The Separation of Corporate Ownership and Control: Theory, Evidence and Implications" (1986) 5 J Accounting Literature 85 (noting that "no consensus has developed" about the impact of equity incentives at 96); Helen Short, "Ownership, Control, Financial Structure and the Performance of Firms" (1994) 8:3 J Economic Surveys 203 (finding that in 1994, long after equity grants became a major component of executive pay, "the results of these studies [were still] inconclusive" at 206); Kenneth J Rediker \& Anju Seth, "Boards of Directors and Substitution Effects of Alternative Governance Mechanisms" (1995) 16:2 Strategic Management J 85 (noting that there is a "singular lack of consistency in the empirical results reported" at 86).

79 See e.g. Internal Revenue Code, 26 USC \& 162(m) (1986) [IRC]. See also Income Tax Act, supra note 56, ss 110(1)(d)-(1)(d.01) as it appeared on 27 February 2000; Balsam, supra note 41 at 3; Bryce C Tingle, Start-up and Growth Companies in Canada: A Guide to Legal and Business Practice, 2nd ed (Markham: LexisNexis, 2013) at 155 [Tingle, Start-up \& Growth Companies].

80 For an extended review of the empirical evidence on this point, see Tingle, "How Good?," supra note $2, \mathrm{nn} 79-92$.

81 Dan R Dalton et al, "Meta-Analyses of Financial Performance and Equity: Fusion or Confusion?" (2003) 46:1 Academy Management J 13 at 18-19 [Dalton et al, "Performance \& Equity"] (a meta-analysis of 229 empirical studies with a combined sample of 939,567 found that with the exception of earnings per share (EPS), the equity exposure of management had no effect on Tobin's Q, return on assets, return on equity, returns on investment, shareholder returns, the market-to-book ratio, Jensen's Alpha and other metrics. The impact to the EPS could be attributed to management techniques designed to increase earnings without changing the performance of the firm); Juan P Sánchez-Ballesta \& Emma GarcíaMeca, "A Meta-Analytic Vision of the Effect of Ownership Structure on Firm Performance" (2007) 15:5 Corporate Governance 879 at 887-88 (a meta-analysis of 33 studies finding that market based-measures of performance appeared to improve with insider equity, but that actual financial performance is unconnected to executive equity levels). See also the discussion in Frydman \& Jenter, supra note 3 at 83-86; Brian L Connelly et al, "Ownership as a Form of Corporate Governance" (2010) 47:8 J Management Studies 1561 at 1564-65 (summarizing the research since 2000 and concluding it is mixed).

82 Sánchez-Ballesta \& García-Meca, ibid at 887. 
At the same time equity plans were demonstrated to be largely irrelevant to corporate performance, they were discovered to be linked to a variety of fraudulent, risky, and suboptimal executive behaviours. ${ }^{83}$ An incomplete list includes: manipulating corporate disclosure,${ }^{84}$ fraud, ${ }^{85}$ earnings management, ${ }^{86}$ restructurings and layoffs, ${ }^{87}$ voluntary corporate dissolutions, ${ }^{88}$ reducing research and development and capital expenditures, ${ }^{89}$ and predatory behaviour in stock repurchases. ${ }^{90}$ Obviously these managerial behaviours harm shareholders, and thus, perfectly contradict the original rationale for adding equity to the traditional pattern of executive pay — cash salaries and bonuses — of the post-war period.

Pay-for-performance, the second remuneration practice contributing to the explosion in executive compensation, first began to receive serious academic attention in the late 1980s and early 1990s when it was argued large portions of executive pay should be contingent on the achievement of certain predefined corporate milestones or accounting metrics. In the post-Enron era, it became conventional wisdom that equity incentives alone allowed executives to profit from market or industry-wide trends without regard to the quality of their decisions (the dot-com asset bubble demonstrated this), and that the prospect of huge paydays from equity incentives might be complicit in the apparently widespread fraudulent behaviour exemplified by Enron and its notorious peers. ${ }^{91}$

For an extended discussion, see this article's companion, Tingle, "How Good?," supra note 2, nn $100-103$.

84 David Aboody \& Ron Kasznik, "CEO Stock Option Awards and the Timing of Corporate Voluntary Disclosures" (2000) 29:1 J Accounting Economics 73 at 75.

85 See e.g. Shane A Johnson, Harley E Ryan Jr \& Yisong S Tian, "Managerial Incentives and Corporate Fraud: The Sources of Incentives Matter" (2009) 13:1 Rev Finance 115 at 116-17; Lin Peng \& Ailsa Röell, "Executive Pay and Shareholder Litigation" (2008) 12:1 Rev Finance 141 at 142; David J Denis, Paul Hanouna \& Atulya Sarin, "Is There a Dark Side to Incentive Compensation?" (2006) 12:3 J Corporate Finance 467 at 468; Joseph P O'Connor Jr et al, "Do CEO Stock Options Prevent or Promote Fraudulent Financial Reporting" (2006) 49:3 Academy Management J 483 at 492-93; Jared Harris \& Philip Bromiley, "Incentives to Cheat: The Influence of Executive Compensation and Firm Performance on Financial Misrepresentation" (2007) 18:3 Organization Science 350 at 361.

86 See e.g. Natasha Burns \& Simi Kedia, "The Impact of Performance-Based Compensation on Misreporting" (2006) 79:1 J Financial Economics 35 at 37; Qiang Cheng \& Terry D Warfield, "Equity Incentives and Earnings Management" (2005) 80:2 Accounting Rev 441 at 443; Daniel Bergstresser \& Thomas Philippon, "CEO Incentives and Earnings Management" (2006) 80:3 J Financial Economics 511 at 514; Jap Efendi, Anup Srivastava \& Edward P Swanson, "Why Do Corporate Managers Misstate Financial Statements? The Role of Option Compensation and Other Factors" (2007) 85:3 J Financial Economics 667 at 670; Julia Grant, Garen Markarian \& Antonio Parbonetti, "CEO Risk-Related Incentives and Income Smoothing" (2009) 26:4 Contemporary Accounting Research 1029 at 1030. Jay Dial \& Kevin J Murphy, "Incentives, Downsizing, and Value Creation at General Dynamics"(1995) 37:3 J Financial Economics 261 at 305; Jeffrey T Brookman, Saeyoung Chang \& Craig G Rennie, "CEO Equity Portfolio Incentives and Layoff Decisions" (2007) 30:2 J Financial Research 259 at 260.

88 Hamid Mehran, George E Nogler \& Kenneth B Schwartz, "CEO Incentive Plans and Corporate Liquidation Policy" (1998) 50:3 J Financial Economics 319 at 320.

89 Alex Edmans, Vivian W Fang \& Katharina A Lewellen, "Equity Vesting and Managerial Myopia" (2015) Centre for Economic Policy Research Working Paper No 10145 at 2, online: <https://papers.ssrn. com/sol3/papers.cfm?abstract_id=2270027>.

$90 \quad$ George W Fenn \& Nellie Liang, "Corporate Payout Policy and Managerial Stock Incentives" (2001) 60:1 J Financial Economics 45 at 47; Jesse M Fried, "The Uneasy Case for Favoring Long-Term Shareholders" (2015) 124:5 Yale LJ 1554 ("over the last forty years, an aggregate of over \$2.3 trillion has been transferred to long-term investors through bargain repurchases and inflated-price equity issuances" at 1564).

91 Bebchuk \& Fried, Pay Without Performance, supra note 24 at 134-36, 139; Bebchuk, Fried \& Walker, supra note 23 at 797; Bebchuk \& Fried, “Agency Problem," supra note 23 at 76, 80-86. 
Pay-for-performance schemes began to proliferate as the new century progressed. ${ }^{92}$ These often had the effect of increasing executive pay levels, as it became necessary to compensate executives for the risk the schemes would not pay out. ${ }^{93}$ There is abundant evidence, for example, that the typical CEO has very little impact on corporate performance. ${ }^{94}$ Sales, earnings, and profit margins are largely determined by the company's industry and its position in that industry. ${ }^{95}$ Corporate leadership changes seem to have relatively minor effects on these performance metrics. ${ }^{96}$ In particular, share price, which is the most important benchmark in pay-for-performance plans (usually in the form of its effect on total shareholder return calculations), fluctuate largely outside of corporate executive control. Scholars estimate that one third to one half of the changes in share prices are attributable solely to market-wide causes. ${ }^{97}$

Tamara C Belinfanti, "Beyond Economics in Pay For Performance" (2012) 41:1 Hofstra L Rev 91 at 103 (by 1993, 35 percent of CEO compensation was attributable to incentive pay; by 2013 this had gone up to nearly 85 percent).

$93 \quad$ See Tingle, "How Good?," supra note 2, nn 45-51.

94 See Xavier Gabaix \& Augustin Landier, "Why Has CEO Pay Increased So Much?” (2008) 123:1 QJ Economics 49 at 50 [Gabaix \& Landier, "CEO Pay"] (study found that the difference in talent between the best CEO in the US and the 250th best only equated to a 0.016 percent increase in market capitalization); Ulrike Malmendier \& Geoffrey Tate, "Superstar CEOs" (2009) 124:4 QJ Economics 1593 at 1595 (research finds that companies led by "superstar" CEOs underperform for up to two years following receipt of important business awards, suggesting, among other things, the importance of factors besides CEO quality); Bebchuk \& Fried, Pay Without Performance, supra note 24 at 139 (share price movements are largely driven by macroeconomic factors that CEOs have little influence over, such as changes to interest rates, economic growth rates, technological changes, and changes to commodity prices); Michael Faulkender et al, "Executive Compensation: An Overview of Research on Corporate Practices and Proposed Reforms" (2010) 22:1 J Applied Corporate Finance 107 at 113-17; Roger L Martin, Fixing the Game: Bubbles, Crashes, and What Capitalism Can Learn from the NFL (Boston: Harvard Business Review Press, 2011) at 25; Dalton et al, "Performance \& Equity," supra note 81 at 18-20. See also Frydman \& Jenter, supra note 3 at 87-89; Connelly et al, supra note 81; SánchezBallesta \& García-Meca, supra note 81 at 887-88; Michel A Habib \& Alexander Ljungqvist, "Firm Value and Managerial Incentives: A Stochastic Frontier Approach" (2005) 78:6 J Business 2053 at 2054-55; Michelle Hanlon, Shivaram Rajgopal \& Terry Shevlin, "Large Sample Evidence on the Relation Between Stock Option Compensation and Risk Taking" (2004) [unpublished] at 24, online: $<$ https://papers.ssrn.com/sol3/papers.cfm?abstract id $=427260>$ (finding a zero to negative association between option risk-taking incentives and future operating performance).

95 See Stanley Lieberson \& James F O'Connor, "Leadership and Organizational Performance: A Study of Large Corporations" (1972) 37:2 American Sociological Rev 117 at 123-24. See also Marianne Bertrand \& Antoinette Schoar, "Managing with Style: The Effect of Managers on Firm Policies" (2003) 118:4 QJ Economics 1169 at 1177 (examining 500 executives in 600 large firms over 30 years and finding leadership changes accounted for only 3 to 4 percent of differences in corporate performance). Bertrand \& Schoar, ibid (leadership changes explained only about 6.5 percent of the variance in sales performance, 5.5 percent of the variance in net income, and 15 percent of the change in profit margin). Victor Brudney \& Marvin A Chirelstein, Cases and Materials on Corporate Finance, 2nd ed (Mineola, NY: Foundation Press, 1979) at 1153; Marianne Bertrand \& Sendhil Mullainathan, "Are CEOs Rewarded For Luck? The Ones Without Principals Are" (2001) 116:3 QJ Economics 901 at 929 (proving that CEOs are compensated based on firm performance, which is dictated by factors not within their control, such as international oil prices); Dirk Jenter \& Fadi Kanaan, "CEO Turnover and Relative Performance Evaluation" (2015) 70:5 J Finance 2155 at 2175-77 (external industry and market shocks like a recession affect CEO turnover, yet these are factors are beyond a CEO's control). 
The adoption of at-risk pay-for-performance schemes has, as a result, not prevented the rise in executive compensation. The basic rule of risk and reward operates in this area, and so potential payouts increase to lottery-like levels. ${ }^{98}$ Pay-for-performance even makes it easier for boards to justify higher remuneration levels to shareholders. This is the case because total shareholder return is often a prominent metric in these plans, and thus, appears to align the rewards received by executives with increases in shareholder wealth.

Like the rise of equity-based compensation a decade earlier, the increasing use of pay-forperformance schemes was both preceded and accompanied by scholarly concern that there was little empirical evidence justifying its prominence. ${ }^{99}$

Academic concerns for the "mixed and inconclusive" evidence for pay-for-performance have continued into the current decade. ${ }^{100}$ Indeed, the best studies performed in the past decade have cast considerable doubt on the merits of pay-for-performance schemes. ${ }^{101}$ For example, using a very large dataset over a long time period (1994 to 2015), the most recent study has found that companies using high levels of incentive pay underperform their peers by surprisingly large amounts, as measured by both stock price and return on assets calculations. $^{102}$

The research by finance scholars in this area is complemented by the work of psychologists who have found, over and over again in laboratory settings, that incentive pay has the effect of weakening motivation and impairing high-level creative or analytical thinking. ${ }^{103}$ It also weakens what Lynn Stout refers to as "prosocial" behaviour. ${ }^{104}$ It is

See Tingle, "How Good?," supra note 2, nn 45-47, 55.

Murphy, "Executive Compensation," supra note 9 ("[u]nfortunately ... there is surprisingly little direct evidence that higher pay-performance sensitivities lead to higher stock-price performance" at 2539); Dennis Wright Michaud \& Yunwei Gai, "CEO Compensation and Firm Performance" (2009) [unpublished], online: $<$ https://papers.ssrn.com/sol3/papers.cfm?abstract_id=1531673>("[w]hat we find disturbing [about using financial incentives in pay packages] is that it was developed as a theoretical proposition rather than a fact confirmed by empirical evidence ... little 'heavy lifting' in empirical statistical research was undertaken" at 7).

Igor Filatotchev \& Deborah Allcock, "Corporate Governance and Executive Remuneration: A Contingency Framework” (2010) 24:1 Academy Management Perspectives 20. See also Frydman \& Jenter, supra note 3 (" $[\mathrm{t}]$ he relative importance of rent extraction and optimal contracting in determining pay for the typical CEO is still to be determined, and even less is known about the causal effects of CEO pay on behavior and firm value" at 96).

See Michael J Cooper, Huseyin Gulen \& P Raghavendra Rau, "Performance for Pay? The Relation Between CEO Incentive Compensation and Future Stock Price Performance" (2016) [unpublished], online: <https://papers.ssrn.com/sol3/papers.cfm?abstract_id=1572085>; Michaud \& Gai, supra note 99 (examining executive pay packages in large US companies and finding that "none of the six payment types had significant effects on firms' performance. This finding suggests a rethinking of the role of CEO compensation as an incentive for improving corporate performance, i.e. can the CEO actually affect the annual profit of firms of this scale" at 1-2).

Cooper, Gulen \& Rau, ibid ("[o]ur results imply that managerial compensation components such as restricted stock, options and long-term incentive payouts, that are meant to align managerial interests with shareholder value, do not always translate into higher future returns, and quite in contrast, for firms with high paid CEOs, translate into lower future shareholder wealth" at 25-26).

This research is discussed in Tingle, "How Good?," supra note 2, nn 88-92. See also Michael B Dorff, Indispensable and Other Myths: Why the CEO Pay Experiment Failed and How to Fix It (Berkeley, University of California Press, 2014) at 128; Andrew CW Lund \& Gregg D Polsky, "The Diminishing Returns of Incentive Pay in Executive Compensation Contracts" (2011) 87:2 Notre Dame L Rev 677 at 689-706 (detailing the reasons to believe that pay-for-performance remuneration schemes' marginal benefits are quite low); Daniel H Pink, Drive: The Surprising Truth About What Motivates Us (New York: Penguin Group, 2009) at 26-58 (describing multiple experiments that show monetary incentives often reduce performance on tasks requiring creativity and persistence).

Lynn A Stout, "Killing Conscience: The Unintended Behavioral Consequences of 'Pay For Performance"" (2014) 39:3 J Corp L 525 at 546-47. 
unsurprising, therefore, that a large body of research connects pay-for-performance incentive schemes with suboptimal corporate behaviour, including fraud and accounting restatements. $^{105}$

To summarize, nearly all of the increase in executive compensation over the past forty years has been due to increases in the use of equity incentives and pay-for-performance schemes (which, in turn, tend to use equity awards). These two compensation practices were almost universally adopted by companies, even as academics at the time expressed concern that enthusiasm was outstripping the state of the empirical research. In each case, when the empirical research caught up it became clear that these compensation practices either produced no improvement in corporate performance or actually impaired it. ${ }^{106}$ Abundant evidence also emerged linking each of these pay practices to fraudulent and short-term executive behaviour.

Agency theory has suggested to most observers, particularly those in the legal and corporate governance communities, that the blame lies with executives and the directors tasked with protecting companies from precisely the sort of risks and failures created by the pay practices we have been considering. But is board failure the best explanation for the current state of affairs?

\section{Who Sets Executive Pay?}

Directors set executive pay with input (as in any negotiation) from the executives themselves. But they do not set pay in a vacuum. Since the time that pay practices began changing, the corporate governance industry has grown into an increasingly loud source of advice to boards. ${ }^{107}$ In many areas, such as the move to independent directors and separating the roles of CEO and chair, boards have adopted the recommendations of the industry due to some combination of external pressure and internal motivation to do what is right. ${ }^{108}$ The remainder of this article takes up the evidence that failures in executive compensation are the result, not of overly powerful CEOs confronting supine boards, but rather, of directors and management earnestly striving to follow bad "best practices" promulgated by the corporate governance industry.

See Bruno S Frey \& Margit Osterloh, "Yes, Managers Should Be Paid Like Bureaucrats" (2005) 14:1 J Management Inquiry 96 at 97 (where CEO compensation is linked to performance, there is a high probability for fraudulent accounting); Harris \& Bromiley, supra note 85 at 362 (linking pay to performance by having options form a high percentage of CEO pay diverts focus from long term firm performance to short term benefits, creating an incentive for illicit behaviour); Denis, Hanouna \& Sarin, supra note 85 ("[a]s the use of stock options increases, the expected payoff from fraud increases" at 470); David A Becher, Terry L Campbell II \& Melissa B Frye, "Incentive Compensation for Bank Directors: The Impact of Deregulation" (2005) 78:5 J Business 1753 at 1759 (equity-based compensation encourages bank managers to take on unjustifiable financial risks); Qiang Cheng \& David B Farber, "Earnings Restatements, Changes in CEO Compensation, and Firm Performance" (2008) 83:5 Accounting Rev 1217 at 1246 (a positive relation exists between CEO option-based compensation and likelihood of earnings restatement; firms that experience earnings restatement often result to decreasing CEO equity holdings); James C Spindler, "Endogenous Compensation in a Firm with Disclosure and Moral Hazard" (2009) University of Southern California Law School Legal Studies Research Paper No 09-41, online: <weblaw.usc.edu/assets/docs/contribute/C09_20_paper.pdf> ("performance-based compensation rewards the faking of performance" at 2).

See Tingle, "How Good?," supra note 2.

See e.g. Tingle, "Corporate Governance," supra note 14. Ibid. 
This is a thesis that is entirely compatible with believing individual boards can, and occasionally have, failed to meet any reasonable construction of their duty in paying their executives. There is ample evidence this happens. ${ }^{109}$ The thesis of this article only claims that these types of board failures do not characterize executive compensation decisions in the English-speaking world; instead, boards generally attempt to follow the best advice available to them on the subject. This is advice, after all, that is backed up by the growing power of institutional shareholders, regulators, proxy advisors, and the media. ${ }^{110}$

\section{A. The Causal Train}

The most perplexing mystery confronting any person attempting to argue the governancefailure position is to explain why the modern problems with executive compensation only arose in the late 1970s. As we have seen, prior to the last years of that decade there was little change in the way executives were compensated, and total pay levels did not grow appreciably following the Second World War. ${ }^{111}$ If the agency cost view of executive compensation is correct, why don't we see runaway compensation in the period from 1950-1980? We have ample evidence that the CEOs of this time were capable of winning over boards and acting in self-interested ways. ${ }^{112}$ The difficulty for the governance-failure school is only increased by the fact that executive pay increased in lock step with the modern corporate governance regime. ${ }^{13}$ It was during the rise in influence of the forces of good governance, including institutional shareholder engagement, when executive pay spiraled upwards and the suboptimal pay practices of equity and performance incentives came into widespread use. ${ }^{114}$

For example, in the American case of In Re Walt Disney Co Derivative Litigation, 907 A 2d 693 (Del Ch 2005), despite the compensation committee members being involved in the negotiations for CEO compensation, and the board later approving the CEO's salary, the CEO was able to receive over US\$140 million following termination of his contract only 15 months into the job.

See Andreas Jansson, “'Real Owners' and 'Common Investors': Institutional Logics and the Media as a Governance Mechanism" (2013) 21:1 Corporate Governance: An Intl Rev 7 at 9; Richard M Buxbaum, "Comparative Aspects of Institutional Investment and Corporate Governance" in Theodor Baums, Richard M Buxbaum \& Klaus J Hopt, eds, Institutional Investors and Corporate Governance (New York: de Gruyter, 1993) 3 at 10-13; Organisation for Economic Co-operation and Development, "The Role of Institutional Investors in Promoting Good Corporate Governance" (2011) at 9, online: $<$ www.oecd.org/daf/ca/49081553.pdf>; Tingle, "Proxy Advisors," supra note 27 at 738-44. See the text accompanying notes 3-9, above.

112 See Brian R Cheffins, "The History of Corporate Governance" (2012) European Corporate Governance Institute Working Paper No 184/2012 at 8-9 [Cheffins, "Corporate Governance History"]; Brian R Cheffins, "History and the Global Corporate Governance Revolution: The UK Perspective" (2001) 43:4 Business History 87 at 89 .

113 See Cheffins, "Corporate Governance History," ibid at 23.

See Benjamin E Hermalin, "Trends in Corporate Governance" (2005) 60:5 J Finance 2351 at 2367-71 (while variations may exist in the short term, the trend shows that as boards become more diligent and independent, CEO compensation rises); Florian S Peters \& Alexander F Wagner, "The Executive Turnover Risk Premium" (2014) 69:4 J Finance 1529 at 1529 (firms tend to fire CEOs for poor industry and firm performance, prompting CEOs to seek higher compensation in riskier business environments); Bebchuk \& Fried, "Agency Problem," supra note 23 at 73; Kevin J Murphy, "Politics, Economics, and Executive Compensation" 63 U Cin L Rev 713 at 739 [Murphy, "Politics"] (arguing performance-based pay leads to higher compensation, being a premium charged by executives for accepting the risk); George P Baker, Michael C Jensen \& Kevin J Murphy, "Compensation and Incentives: Practice vs. Theory" (1988) 43:3 J Finance 593 (current pay schemes are "largely independent of performance" at 594); Michael C Jensen \& Kevin J Murphy, "CEO Incentives - It's Not How Much You Pay, But How" (1990) 68:3 Harvard Business Rev 138 at 138, 140-43 [Jensen \& Murphy, "CEO Incentives"]; Stout, supra note 104 ("[i]n the early 1990s ... the idea of incentive pay captured the hearts and minds of reformers and business leaders alike" at 532); CCGG, "Executive Compensation," supra note 35 at 1; Bebchuk \& Fried, Pay Without Performance, supra note 24 at 61-62; Troy A Paredes, "Blinded by the Light: Information Overload and Its Consequences for Securities Regulation" (2003) 81:2 Wash ULQ 417 at 464 (discussing the use of disclosure to influence corporate conduct). See also Eric D Roiter, "Illegal Corporate Practices and the Disclosure Requirements of the Federal Securities Laws" 
Another suspicious fact is that the agents of the growth in executive compensation equity and performance incentives — are the very pay practices that have been historically recommended by the corporate governance industry. ${ }^{115}$ The CCGG identifies pay-forperformance as the "focus" of its "Executive Compensation Principles." "116 ISS proxy voting guidelines are focused almost exclusively on pay-for-performance considerations. ${ }^{117}$ Even the election of directors is linked to companies' adherence to pay-for-performance orthodoxy. ${ }^{118}$ Reflecting widespread institutional shareholder sentiment, the Ontario Teachers' Pension Plan (OTPP) advises in its published proxy voting guide that its voting decisions will be tightly associated with corporate adherence to pay-for-performance structures. ${ }^{119}$ Finally, Canadian securities regulators require companies to disclose repeatedly - the ways in which executive compensation is connected to performance. ${ }^{120}$

In relation to the use of equity incentives generally, the corporate governance industry is similarly monolithic in its approval of equity as a legitimate device for aligning shareholder and executive interests. The Canadian and US governments signaled this via tax changes explicitly designed to make the awarding of equity compensation significantly more attractive than the old practice of cash salaries and bonuses. ${ }^{121}$ Canadian securities regulators have, since the early 1990s, required Canadian issuers to provide a graph in their annual

(1982) 50:5 Fordham L Rev 781 at 785-86 (discussing the self-conscious use of disclosure by securities regulators to deter certain kinds of corporate conduct); Stephen M Salley, "Fixing' Executive Compensation: Will Congress, Shareholder Activism, or the New SEC Disclosure Rules Change the Way Business is Done in American Boardrooms?" (2009) 70:3 Ohio St LJ 757 at 765-66; Tod Perry \& Marc Zenner, "CEO Compensation in the 1990s: Shareholder Alignment or Shareholder Expropriation?" (2000) 35:1 Wake Forest L Rev 123 at 124 (indicating that prior to 1993, most executives were compensated with fixed salaries and discretionary bonuses); Belinfanti, supra note 92 at 103; Thomas Lemieux, W Bentley MacLeod \& Daniel Parent, "Performance Pay and Wage Inequality" (2009) 124:1 QJ Economics 1 at 2-3; Matt Fullbrook, "Strong Pay for Performance on the TSX 60 Since 2004" (January 2013), Rotman School of Management - University of Toronto at 1, online: $<$ https://www.rotman.utoronto.ca/-/media/Files/Programs-and-Areas/CCBE/TSX\%2060\%20Pay $\% 20$ for\%20Performance.pdf $>$; Conyon, "Executive Compensation," supra note 7 at F62, F79. See also the text accompanying notes 68-71 and 121-26.

115 For an in-depth discussion, see Tingle, "How Good?," supra note 2, nn 57-78.

116 CCGG, "Executive Compensation," supra note 35 at 1. See also Baker, Jensen \& Murphy, supra note 114 at 594; Jensen \& Murphy, "CEO Incentives," supra note 114 at 140-43.

117 ISS, "2015 FAQ," supra note 28; Institutional Shareholder Services, "Frequently Asked Questions on U.S. Compensation Policies" (28 March 2014), online: <https://www.issgovernance.com/file/2014 Policies/ISSUSCompensationFAQs03282014.pdf> (the "ISS is not likely to recommend a vote for the compensation committee members and/or vote for the management say on pay or equity plan proposal unless the company has provided compelling and sufficient evidence of action to strengthen the performance-linkage to its executives' compensation" at 16); Institutional Shareholder Services, "Canada Proxy Voting Guidelines for TSX-Listed Companies: 2016 Benchmark Policy Recommendations" (18 December 2015), online: <https:/www.issgovernance.com/file/policy/2016canada-tsx-voting-guidelines-dec-2015.pdf $>$ [ISS, "Voting Guidelines"] (there are five principles driving the ISS's voting recommendations, two of which are essentially reiterations of pay-forperformance: "[m]aintain appropriate pay-for-performance alignment with emphasis on long-term shareholder value" and "[a]void arrangements that risk "pay for failure"" at 29).

118 ISS, "Voting Guidelines," ibid at 5, 9.

119 Ontario Teachers' Pension Plan, "Good Governance Is Good Business: 2017 Corporate Governance Principles and Proxy Voting Guidelines" (2017), online: < https://www.otpp.com/documents/10179/ 20940/TeachersCorpGovE.pdf/cfca9682-9368-4cf4-96ce-fe5381d5647e> ("[i]ncentive compensation plans ... should be closely related to individual and corporate performance" at 26). Statement of Executive Compensation, OSC Form 51-102F6, (2008) 31 OSCB 12047 (19 December 2008), ss 2.1(1)(b), (3), (4) [OSC Form 51-102F6]; Corporate Governance Guidelines, OSC NP 58-201, (2005) 28 OSCB 5383 (17 June 2005) (the CSA advises that "[ $t$ ] he compensation committee should be responsible for ... reviewing and approving corporate goals and objectives relevant to CEO compensation, evaluating the CEO's performance in light of those corporate goals and objectives, and determining ... the CEO's compensation level based on this evaluation," s 3.17). See supra note 79 . 
executive compensation report showing cumulative total shareholder return for the company, measured against a broad equity market index. ${ }^{122}$ The purpose of this disclosure requirement is not to inform the shareholders about the relative performance of the stock (shareholders are well aware of this fact). Rather, its placement in the executive compensation report is designed to encourage companies to ensure their executive pay does not deviate much from share price performance - a strong incentive to use equity as the principal component of an executive's pay package. ${ }^{123}$

The other participants in the corporate governance industry share this bias towards equitybased pay. The OTPP's proxy voting guidelines and CCGG's "High Performance Boards" assume equity compensation will be used and only concern themselves with identifying unacceptable types of grants. ${ }^{124}$ The constant recourse in both documents to total shareholder return and increases in shareholder wealth as the litmus tests for appropriate compensation arrangements strongly encourages the use of equity pay. Only equity instruments mirror the gains and losses experienced by shareholders. Indeed, shareholders bid up the stock of companies that announce equity incentive packages. ${ }^{125}$ There is even a positive relationship between CEO option holdings and initial public offering (IPO) valuations. ${ }^{126}$

At the very least, the evidence suggests that boards have not been alone in favouring the use of equity and pay-for-performance compensation arrangements. Directors have been part of a widespread trend that has included the most influential members of the corporate governance movement. But who has influenced whom? Has the corporate governance industry been merely trying to keep up with corporate practice and contain the worst excesses, or have boards responded to the best practices emanating from industry participants, including academics, governments, regulators, and institutional shareholders?

The direction of causality might be discerned in the varied history of stock options in the US and UK. It is difficult to remember now, but in the 1980s and early 1990s, the use of stock options was strongly encouraged by leading finance scholars. ${ }^{127}$ Even the Canadian and US legislatures used tax laws to signal the desirability of stock options. ${ }^{128}$ Throughout the 1990s, institutional shareholders, such as the California Public Employees' Retirement System (CalPERS) and governance think tanks like the National Association of Corporate Directors, advocated for greater use of options. ${ }^{129}$ In 2000, the Harvard Business Review opined, "[o]ptions are the best compensation mechanism we have for getting managers to act

OSC Form 51-102F6, supra note 120, s 2.2(b).

As I have indicated elsewhere, for most Canadian companies, total shareholder return is largely made up of share price increases, as dividends are rarely paid by most Canadian public companies. See Tingle, "Proxy Advisors," supra note 27 at 742.

CCGG, "High Performance Boards," supra note 34 ("[e]xecutives also should have meaningful shareholdings in the company to more closely align their interests with shareholders" at 19); OTPP, supra note 119 at 28 (generally supporting equity plans that are reasonable).

Angela G Morgan \& Annette B Poulsen, "Linking Pay to Performance - Compensation Proposals in the S\&P 500" (2001) 62:3 J Financial Economics 489 at 491.

$\mathrm{S}$ Trevis Certo et al, "Giving Money to Get Money: How CEO Stock Options and CEO Equity Enhance IPO Valuations" (2003) 46:5 Academy Management J 643 at 644-45.

See Jensen \& Murphy, "CEO Incentives," supra note 114.

See Income Tax Act, supra note 56, ss 110(1)(d)-(1)(d.01) as it appeared on 27 February 2000; IRC, supra note $79, \S 162(\mathrm{~m})$.

Shamsud D Chowdhury, "Director Compensation: The Growing Popularity of Deferred Stock Units" (2009) 73:1 Ivey Business J 11, online: <www.iveybusinessjournal.com/publication/director-compen sation-the-growing-popularity-of-deferred-stock-units/>. 
in ways that ensure the long-term success of their companies and the well-being of their workers and stockholders." ${ }^{130}$ Corporate behaviour followed this consensus, with the 1990s being marked by increasing use of options as a remuneration package. ${ }^{131}$

Then, suddenly, stock options fell out of general favour with the corporate governance industry in the years after the dot-com collapse. ${ }^{132}$ The recommended alternative in the US was restricted share grants. ${ }^{133}$ As we would expect, boards began to abandon stock options very quickly in favour of restricted share grants, which are now a more important source of pay than options. ${ }^{134}$ By 2012, restricted stock grants contributed 35 percent of the average CEO's pay, compared to the 14 percent from options. ${ }^{135}$

In the UK, conversely, the corporate governance industry began to criticize options much earlier than occurred in the US, at least in part because of their role in outsized compensation gains received by British executives when their utilities were privatized in the early $1990 \mathrm{~s} .{ }^{136}$ The 1995 Greenbury committee report recommended the use of "challenging performance criteria" as conditions for option exercise, and this was embraced by other elements of the governance industry. ${ }^{137}$ The Association of British Insurers, which sets influential governance best practices (and in this respect functions similarly to proxy advisory firms in North America), issued guidelines in 1994 that suggested options should be constrained to four times cash compensation. The result was that stock option use declined sharply in the UK well before they did in the US and that, also unlike the US, performance-vesting now predominates in that country. ${ }^{138}$

Hall, "Stock Options," supra note 74 at 122

Jerry W Markham, A Financial History of Modern US Corporate Scandals: From Enron to Reform, (New York: ME Sharpe, 2006) at 32 (by the end of the decade, 80 percent of executive compensation was paid in options and the number of employees in America receiving options had risen from 1 million to 10 million).

132 See e.g. Ingolf Dittmann \& Ernst Maug, "Lower Salaries and No Options? On the Optimal Structure of Executive Pay" (2007) 62:1 J Finance 303 at 318; Brian J Hall \& Kevin J Murphy, "Stock Options for Undiversified Executives" (2002) 33:1 J Accounting \& Economics 3 at 28; Bebchuk \& Fried, "Agency Problem," supra note 23 at 83-85; Harley E Ryan Jr \& Roy A Wiggins III, "The Interactions Between R\&D Investment Decisions and Compensation Policy" (2002) 31:1 Financial Management 5 at 27 (noting that option awards to managers encourage them to invest with more risk). As well, the 2001 and 2008 financial crises were widely blamed — at least in part — on the use of stock options: see Sanjai Bhagat \& Brian Bolton, "Financial Crisis and Bank Executive Incentive Compensation" (2014) 25 J Corporate Finance 313 at 313; Hamid Mehran, Alan Morrison \& Joel Shapiro, "Corporate Governance and Banks: What Have We Learned from the Financial Crisis?" (2011) Federal Reserve Bank of New York Staff Report No 502 at 7-8, online: <https://www.newyorkfed.org/research/staff_reports/ sr502.pdf>; Kevin J Murphy, "Pay, Politics, and the Financial Crisis" in Alan S Blinder, Andrew W Lo $\&$ Robert M Solow, eds, Rethinking the Financial Crisis (New York: Russell Sage Foundation, 2012) 303.

Hall \& Murphy, ibid; Martin J Conyon, "Executive Compensation and Incentives"(2006) 20:1 Academy Management Perspectives 25 at 28 [Conyon, "Compensation \& Incentives"]. Conyon, "Executive Compensation," supra note 7 at F72, F74-F75.

Ibid at F75; Conyon et al, "Compensation Controversy," supra note 42 at 26 (between 1992-2009, the percentage of companies making restricted share grants tripled from 24 to 75 percent).

Conyon et al, "Compensation Controversy," ibid at 64.

Study Group on Directors' Remuneration, "Directors' Remuneration: Report of a Study Group Chaired by Sir Richard Greenbury" (17 July 1995) at 17, online: European Corporate Governance Institute $<$ www.ecgi.org/codes/documents/greenbury.pdf $>$.

See Martin J Conyon, John E Core \& Wayne R Guay, "Are US CEOs Paid More Than UK CEOs? Inferences from Risk-Adjusted Pay" (2011) 24:2 Rev Financial Studies 402 at 404-409; Martin J Conyon \& Kevin J Murphy, "The Prince and the Pauper? CEO Pay in the United States and United Kingdom" (2000) 110:467 Economic J F640; Conyon et al, "Compensation Controversy," supra note 42 at $65-66$. 
After considering and rejecting the limited agency cost explanations for the different patterns and levels of compensation between the US and the UK, one team of scholars concluded, "[o]verall, there are no compelling agency-theoretic explanations for the relative reliance on equity-based compensation in the United States." ${ }^{139}$ Obviously, the differences are due to historical changes in the recommendations of influential members of the governance industry. The best evidence we have at our disposal on the question of causality suggests that boards follow, and do not lead, the consensus best practices developed by the corporate governance industry. Finance scholars themselves recognize (often ruefully) that boards are significantly influenced by academic theories about executive pay and the ways these theories are popularized. ${ }^{140}$

If you ask executives themselves about why they have adopted performance pay schemes, they will usually tell you it is in response to governance industry advice and pressure. Even as incentive pay dominates compensation schemes, surveys of executives find they do not actually believe that performance pay materially impacts their behaviour. ${ }^{141}$

\section{B. THE EFFECTS OF BOARD MONITORING}

If the governance-failure explanation for executive pay problems was accurate, we would expect to see that changes in governance structures which increase the independence and power of the directors relative to the CEO lead to better pay practices. Fortunately, the period we have been considering has been marked by significant changes to corporate governance regimes, which affords an opportunity to test the theory.

The most significant change has been the rise in independent directors, which have gone from constituting approximately 20 percent of boards in $1950^{142}$ to comprising 84 percent in $2014 .{ }^{143}$ Most of the increase in independent directors has occurred since the late $1970 \mathrm{~s}$ as a logical consequence of the adoption of modern corporate governance agency theory. ${ }^{144}$ When it comes to the impact of this trend on executive pay levels, even as far back as 1994 and 1999, scholars were reporting that firms with a higher fraction of outside directors were

Conyon et al, "Compensation Controversy," ibid at 61.

140 See ibid ("we believe that there are three main factors that fueled the explosion in stock options: (1) increased shareholder activism and demands that pay be better linked to shareholder returns" at 15); Kevin J Murphy, "Executive Compensation: Where We Are and How We Got There" in George M Constantinides, Milton Harris \& René M Stulz, eds, Handbook of the Economics of Finance, vol 2A (Amsterdam: Elsevier, 2013) 211 at 284 (discussing the influence of his work, with Michael Jensen arguing for increased use of stock options); Frank Dobbin \& Jiwook Jung, "The Misapplication of Mr Michael Jensen: How Agency Theory Brought Down the Economy and Why It Might Again" in Michael Lounsbury \& Paul M Hirsch, eds, Markets on Trial: The Economic Sociology of the U.S. Financial Crisis: Part B (Bingley, UK: Emerald Group, 2010) 29 at 33-34 (shareholders and boards tend to adopt expert responses to market challenges).

See e.g. Michael Beer \& Nancy Katz, "Do Incentives Work? The Perceptions of a Worldwide Sample of Senior Executives" (2003) 26:3 Human Resource Planning 30 at 36 (when interviewed, executives revealed that contrary to popular belief, their day-to-day business decision-making was not influenced by the incentives they expected to receive). Jeffrey N Gordon, "The Rise of Independent Directors in the United States, 1950-2005: Of Shareholder Value and Stock Market Prices" (2007) 59:6 Stan L Rev 1465 at 1475 [Gordon, "The Rise"]. com/ /media/pdf\%20files/research\%20and\%20insight\%20pdfs/SSBI2014web14Nov2014.pdf>. 
more likely to reward executives with higher remuneration. ${ }^{145}$ The reason for this, as suggested by studies, is that independent directors were correlated with a greater use of equity compensation structures. ${ }^{146}$

Later studies confirmed these initial findings that greater board independence leads to higher executive pay. ${ }^{147}$ A 2005 meta-analytic review of research in the area that included more than 30,000 observations found no evidence that independent boards did better at controlling executive pay. ${ }^{148}$ The study concluded that the results provide "little support to agency theory predictions" of the impact of board composition on critical decisions that involve a potential conflict of interest between managers and shareholders. ${ }^{149}$

Once again, the research in this area seems compatible with the big picture visible to any interested observer. Increasingly independent boards over the past 35 years have been accompanied by increasing pay levels and the adoption of equity and performance incentives. That finance scholarship in this area is mostly useful for confirming the connection between the trends is not accidental.

Compensation committees are another device designed to provide better independent oversight of executive compensation decisions. The original theory behind compensation committees was that a small number of directors should be given direct responsibility to set executive pay, to avoid the possibility of pluralistic ignorance and what social scientists call the "bystander effect," which occurs when no one takes responsibility for a problem, instead assuming or hoping someone else in a large group will. ${ }^{150}$ To this rationale was added a norm of independence in the 1990s, so that compensation committees came to be seen primarily as a way of providing greater independence in remuneration decisions than can be supplied by a majority, or even super-majority, independent board. Over the past two decades, these committees have thus come to be made up exclusively of independent directors. ${ }^{151}$

See Brian K Boyd, "Board Control and CEO Compensation” (1994) 15:5 Strategic Management J 335 at 339; John E Core, Robert W Holthausen \& David F Larcker, "Corporate Governance, Chief Executive Officer Compensation, and Firm Performance" (1999) 51:3 J Financial Economics 371 at 372. Hamid Mehran, "Executive Compensation Structure, Ownership, and Firm Performance" (1995) 38:2 J Financial Economics 163 at 173.

147 Martin J Conyon \& Lerong He, "Compensation Committees and CEO Compensation Incentives in US Entrepreneurial Firms" (2004) 16 J Management Accounting Research 35 at 47 (boards with a greater percentage of inside directors are correlated with lower total CEO compensation); Kam-Ming Wan, "Can Boards with a Majority of Independent Directors Lower CEO Compensation?" (2009) [unpublished, archived at University of Hong Kong] at 5, online: $<$ https://papers.ssrn.com/sol3/papers. cfm?abstract_id=1421549>; Joseph Gerakos, "CEO Pensions: Disclosure, Managerial Power, and Optimal Contracting" (2010) [unpublished, archived at University of Chicago Booth School of Business] at 4, online: $<$ https://papers.ssrn.com/sol3/apers.fm?abstract_id $=982180>$ (finding that outside directors are associated with higher levels of CEO pension benefits and less accurate public disclosure about those benefits); Conyon, "Executive Compensation," supra note 7 at F86 (little evidence pay levels are connected to the percentage of inside directors).

148 Yuval Deutsch, "The Impact of Board Composition on Firms' Critical Decisions: A Meta-Analytic Review" (2005) 31:3 J Management 424 at 433.

149 Ibid at 438 .

150 See James D Westphal \& Michael K Bednar, "Pluralistic Ignorance in Corporate Boards and Firms' Strategic Persistence in Response to Low Firm Performance" (2005) 50:2 Administrative Science Q 262; Jonathon RB Halbesleben \& M Ronald Buckley, "Social Influences on Performance Evaluation: Implications for the Development of Performance Standards" (2009) 14:3 J Applied Management \& Entrepreneurship 74.

151 See e.g. IRC, supra note 79, $\S 162(\mathrm{~m})$, introduced in 1993, required independence on the committee as a prerequisite for deductibility, the 2003 NYSE listing requirements refined the definition of "independent" in relation to service on the committee, and Dodd-Frank Act, supra note 44, §952 further tightened the definition of "independent." See also Conyon, "Executive Compensation," supra note 7 at F75 (finding 98 percent of directors on compensation committees in the US and UK are independent). 
The effects of compensation committees are similar to those we have seen with independent directors generally. Seven different studies have found that compensation committees with a higher proportion of outside directors have no significant impact on the level of CEO compensation, ${ }^{152}$ with several studies finding a committee comprised entirely of independent directors actually leads to higher executive pay. ${ }^{153}$

Yet another device that provides greater independence to boards is the increasingly common retention of compensation consultants. Third party consultants provide directors with a source of information about the market for executive talent independent from the CEO or his subordinates in the company's human resources team. As well, compensation consultants present themselves as experts on optimal pay structures, shareholder and proxy advisor expectations, and evolving trends in good governance. ${ }^{154}$ Market checks conducted by third party consultants provide directors with arguments to counter aggressive CEO proposals. Compensation consultants barely existed in 1980 but are now ubiquitous, ${ }^{155}$ partly as a result of the growing complexity of "best practices" when it comes to remuneration structures. ${ }^{156}$

See Conyon, "Executive Compensation," ibid at F80 (finding compensation grew post-Dodd-Frank at the same rate as before, and that growth is unaffected by the composition of the compensation committee); Conyon \& He, supra note 147 at 50-52; Catherine M Daily et al, "Compensation Committee Composition as a Determinant of CEO Compensation" (1998) 41:2 Academy Management J 209 at 214; Harry A Newman \& Haim A Mozes, "Does the Composition of the Compensation Committee Influence CEO Compensation Practices?" (1999) 28:3 Financial Management 41 at 50; Ian Gregory-Smith, "Chief Executive Pay and Remuneration Committee Independence"(2012) 74:4 Oxford Bulletin Economics \& Statistics 510 at 528 (no statistical relationship between CEO compensation and non-independent directors); Martin J Conyon \& Danielle Kuchinskas, "Compensation Committees in the United States" in Christine A Mallin, ed, Handbook on International Corporate Governance: Country Analyses (Cheltenham, UK: Edward Elgar, 2006) 151 at 154; Nikos Vafeas, "Further Evidence on Compensation Committee Composition as a Determinant of CEO Compensation" (2003) 32:2 Financial Management 53 at 69; Ronald C Anderson \& John M Bizjak, "An Empirical Examination of the Role of the CEO and the Compensation Committee in Structuring Executive Pay" (2003) 27:7 J Banking \& Finance 1323 at 1326.

Wan, supra note 147 at 14; Martin J Conyon \& Simon I Peck, "Board Control, Remuneration Committees, and Top Management Compensation" (1998) 41:2 Academy Management J 146 at 154 (CEO pay is higher in firms with compensation committees and those with a greater fraction of independent directors on the committee).

See Brian Cadman, Mary Ellen Carter \& Stephen Hillegeist, "The Incentives of Compensation Consultants and CEO Pay" (2010) 49:3 J Accounting \& Economics 263 (discussing consultants' "access to detailed, proprietary information about pay practices" at 264); Ruth Bender, "Paying for Advice: The Role of the Remuneration Consultant in UK Listed Companies" (2011) 64:2 Vand L Rev 361 (documenting the role of compensation consultants as providers of expert advice and proprietary data). See Martin J Conyon, Simon I Peck \& Graham V Sadler, "Compensation Consultants and Executive Pay: Evidence from the United States and the United Kingdom" (2009) 23:1 Academy Management Perspectives 43 at 49 (finding only a minority of companies in the sample did not use a compensation consultant); Jenny Chu, Jonathan Faasse \& P Raghavendra Rau, "Do Compensation Consultants Enable Higher CEO Pay? New Evidence from Recent Disclosure Rule Changes" (2016) [unpublished, archived at University of Cambridge] at 31, online: <https://papers.ssrn.com/sol3/papers.cfm?abstract id $=2500054>$ (noting that 91 percent of the firms in their sample retained consultants); John M Bizjak, Michael L Lemmon \& Lalitha Naveen, "Does the Use of Peer Groups Contribute to Higher Pay and Less Efficient Compensation?" (2008) 90:2 J Financial Economics 152 at 154 (finding that 65 percent of firms referred to consultants in their proxy statements). (2010) 49:3 J Accounting \& Economics 247 at 247 (finding consulting firms are associated with more complex forms of CEO pay). 
Research on the impact of compensation consultants finds their use is associated with higher executive pay, largely because of greater use of equity and performance incentives. ${ }^{157}$ Pay levels in a company increase immediately following the retention of a consulting firm. ${ }^{158}$ In the words of a large recent study, "the increase in total pay is largely due to higher equity based incentive pay." 159 Studies of foreign firms using US compensation consultants find their pay levels and structures more closely resemble those of the US than their country of origin, "consistent with this practice [the use of consultants] being a transmission mechanism for pay practices.","160

Several studies have debunked the claim that pay outcomes are driven by conflicts of interest on the part of the consultants. ${ }^{161}$ The best reading of the evidence, therefore, is that compensation consultants produce higher pay because they recommend best practices that, as we have seen, are responsible for nearly all modern pay growth.

Over the past 30 years, boards have steadily grown more independent from management. This can be seen, for example, in the long-term rate increases in disciplinary terminations of underperforming CEOs. ${ }^{162}$ Yet, these increasingly independent boards are awarding increasing amounts of pay to CEOs, and making increasing use of suboptimal compensation structures. Indeed, as we examine each corporate governance practice designed to increase board freedom from managerial power, we find evidence that these liberating practices are associated with higher pay and greater use of equity and performance incentives. These are facts that are incompatible with the governance-failure narrative of executive compensation.

A final inconvenient fact for the governance-failure approach arises from the secular trend of hiring external candidates for the top corporate positions (itself evidence of an erosion in the power of management teams). In the $1970 \mathrm{~s}$, fewer than 15 percent of CEOs were hired externally; this had risen to a third of hires by the end of the century. ${ }^{163}$ Researchers find that externally hired CEOs are paid more than internal candidates who assume the position. ${ }^{164}$ Indeed, the median pay of external hires is higher than that of the CEOs they replace,

See Conyon, Peck \& Sadler, supra note 155 at 43 (finding that the level of CEO pay is higher in companies that use compensation consultants, that equity-based pay is greater in firms that use consultants, and that both these findings are generally consistent with other concurrent research in the UK and the US); James B Wade, Joseph F Porac \& Timothy G Pollock, "Worth, Words, and the Justification of Executive Pay" (1997) 18 J Organizational Behavior 641 at 644; Chu, Faasse \& Rau, supra note 155 at 3 (finding CEOs of firms using consultants earn significantly higher pay, driven both by growth in salary and benefits (5.6 percent higher) and equity pay (21.7 percent higher)). Chu, Faasse \& Rau, ibid.

Ibid at 24.

Joseph J Gerakos, Joseph D Piotroski \& Suraj Srinivasan, "Which US Market Interactions Affect CEO Pay? Evidence from UK Companies" (2013) 59:11 Management Science 2413 at 2414.

161 See Cadman, Carter \& Hillegeist, supra note 154 at 264 (investigating and finding little evidence to show that consultants' conflicts of interest result in higher executive remuneration); Conyon, Peck \& Sadler, supra note 155 ("there is little evidence that [compensation consultants] with potential conflicts of interests, such as supplying other business to client firms, leads to greater CEO pay" at 43); Murphy \& Sandino, supra note 156 at 247 (finding consultants hired by management are associated with lower pay levels than consultants hired by the board). But see Chu, Faasse \& Rau, supra note 155 at 6 (finding that management-retained consultants do lead to higher pay than board-retained consultants). See e.g. Steven N Kaplan \& Bernadette A Minton, "How Has CEO Turnover Changed?" (2012) 12:1 Intl Rev Finance 57 at 75; Mark R Huson, Robert Parrino \& Laura T Starks, "Internal Monitoring Mechanisms and CEO Turnover: A Long-Term Perspective" (2001) 56:6 J Finance 2265 at 2267-68. Kevin J Murphy \& Jan Zabojnik, "Managerial Capital and the Market for CEOs" (2007) at 1-2, online: $<$ https://papers.ssrn.com/sol3/papers.cfm?abstract_id=984376>. Ibid. 
notwithstanding that external candidates have presumably little influence over the board of strangers hiring them.

\section{The INFLUENCE OF SHAREHOLDERS}

Shareholders comprise the constituency most directly harmed by executive pay practices. If the percentage of profits allocated to senior executives has more than doubled in America in the last thirty years, this money has come out of the pockets of investors as the residuary interest holders. ${ }^{165}$ If governance failures were the correct explanation for what has been going wrong with executive compensation, we should expect to see evidence that shareholder power is used to correct abuses. ${ }^{166}$

Institutional shareholders are generally strong believers in the use of equity and pay-forperformance incentive schemes. This is visible in the proxy voting guidelines published by some of the larger investors, such as the OTPP, ${ }^{167}$ as well as the voting guidelines published by proxy advisory firms, whose business is catering to the prejudices (generally unsupported by empirical evidence) of their institutional clientele. ${ }^{168}$ Think tanks and advocacy groups who receive their financial support from institutional investors also faithfully advocate the executive compensation best practices we have been considering. ${ }^{169}$

Shareholder belief in these pay structures is sincere. Studies have repeatedly found that the market rewards companies that adopt equity and performance incentive schemes. We see evidence of shareholders' positive reactions to public announcements of these structures ${ }^{170}$ in the higher valuation of IPO candidates making use of these structures, ${ }^{171}$ and in the improvement in market-related performance measures for companies using these structures (even if actual corporate financial performance is unaffected). ${ }^{172}$

Private equity affords the best test case for the impact of shareholder power on executive remuneration, as private equity firms intensively manage their portfolio companies. The boards of these companies are almost entirely constituted by representatives of the shareholders, and these directors, along with other representatives of the shareholders, tend to be deeply engaged in the day-to-day running of the business in a way that is alien to

See the text accompanying at notes 10-11, above.

Ertimur, Ferri \& Muslu, supra note 64 at 537-38.

See OTPP, supra note 119.

See Tingle, "Proxy Advisors," supra note 27 at 743-47.

See Baker, Jensen \& Murphy, supra note 114 at 594; Jensen \& Murphy, "CEO Incentives," supra note 114 at 138, 140-43; Stout, supra note 104 ("[i]n the early 1990 s ... the idea of incentive pay captured the hearts and minds of reformers and business leaders alike" at 532); CCGG, "Executive Compensation," supra note 35 at 1; Bebchuk \& Fried, Pay Without Performance, supra note 24; OSC Form 51-102F6, supra note 120, s 2.2(b); Paredes, supra note 114 at 417, 464; Roiter, supra note 114 at 781, 785-86; Salley, supra note 114 at 765-66; CCGG, "High Performance Boards," supra note 34 ("[e]xecutives also should have meaningful shareholdings in the company to more closely align their interests with shareholders" at 19); Tingle, Start-up \& Growth Companies, supra note 79 at 155; OTPP, supra note 119 at 28; Morgan \& Poulsen, supra note 125 at 491; Certo et al, supra note 126 at 644-45. See also notes $115-18$.

OTPP, ibid at 28 (generally supporting equity plans that are reasonable); Morgan \& Poulsen, ibid.

Dorff, supra note 103 at 128; Lund \& Polsky, supra note 103 at 689-706 (detailing the reasons to believe pay-for-performance remuneration schemes' marginal benefit are quite low).

Sánchez-Ballesta \& García-Meca, supra note 81 at 887-88. 
comparable public company boards. ${ }^{173}$ The scope for the kind of agency cost governance failures assumed by the governance industry would appear to be very circumscribed.

Yet, studies performed on private equity-backed companies find they compensate their executives in precisely the same way as other businesses. ${ }^{174}$ The pay levels of CEOs in private equity-backed firms are "statistically indistinguishable" from those of public companies, as are the value of stock and stock options granted to these officers. ${ }^{175}$ In fact, executive remuneration actually goes up when companies go private, ${ }^{176}$ and over the past three decades, pay in closely-held firms has outpaced that of public companies. ${ }^{177}$ Again, this phenomenon appears to be linked to greater use of equity incentives. ${ }^{178}$

Given widespread shareholder commitments to suboptimal pay practices, we should not be surprised that various initiatives designed to increase shareholder influence over compensation in the public markets have had no real impact on existing practices. It is vanishingly rare for a company to lose a say-on-pay vote ${ }^{179}$ (suggesting boards are largely doing what shareholders want done), and in neither the US nor the UK is there any evidence that say-on-pay proposals change the level or growth of CEO pay. ${ }^{180}$ Indeed, pay in the UK, which introduced mandatory say-on-pay votes in 2002, increased at greater rates than the US over the following decade. ${ }^{181}$ The only impact of say-on-pay (aside from rising pay levels) has been, in the words of Jeffrey Gordon, to encourage firms to "follow the guidelines, stay in the middle of the pack, and avoid change from a prior year, when the firm received a favorable vote." 182 In other words, say-on-pay has brought "stasis rather than innovation"183 to companies.

There is very little evidence in the social science literature to support the idea that directors, as agents, are deviating from what their principals, the shareholders, would like

See Michael C Jensen, "Eclipse of the Public Corporation" (1989) 67:5 Harvard Business Rev 61 at 61; Ronald W Masulis \& Randall S Thomas, "Does Private Equity Create Wealth? The Effects of Private Equity and Derivatives on Corporate Governance" (2009) 76:1 U Chicago L Rev 219 at 219-20.

Robert J Jackson Jr, "Private Equity and Executive Compensation" (2013) 60:3 UCLA L Rev 638 at 652.

175 Ibid at 652,655

176 Henrik Cronqvist \& Rudiger Fahlenbrach, "CEO Contract Design: How Do Strong Principals Do It?" (2013) 108:3 J Financial Economics 659 at 663.

177 Steven N Kaplan, "Executive Compensation and Corporate Governance in the United States: Perceptions, Facts, and Challenges" (2012) 2 Cato Papers on Public Policy 99 at 102 [Kaplan, "Facts \& Challenges"].

178 Cronqvist \& Fahlenbrach, supra note 176 at 660.

179 Jeffrey N Gordon, "'Say On Pay': Cautionary Notes on the UK Experience and the Case for Shareholder Opt-In" (2009) 46:2 Harv J on Legis 323 at 343 [Gordon, "Say On Pay"] (noting that since the inception of say-on-pay in 2002, British companies lost only 8 votes); Conyon, "Executive Compensation," supra note 7 at F83 (noting that 98 percent of executive pay packages are approved in the US and more than four-fifths of companies had votes in favour in excess of 80 percent).

180 Fabrizio Ferri \& David A Maber, "Say on Pay Votes and CEO Compensation: Evidence from the UK" (2013) 17:2 Rev Finance 527 at 529; Martin Conyon \& Graham Sadler, "Shareholder Voting and Directors' Remuneration Report Legislation: Say on Pay in the UK" (2010) 18:4 Corporate Governance: An Intl Rev 296 at 297 (finding little evidence that average CEO pay fell following adverse voting, or that there were large changes in CEO pay structure).

181 Gordon, "Say On Pay," supra note 179 at 344.

$182 \quad$ Ibid at 347.

Ibid at 348. See also Lund \& Polsky, supra note 103 (say-on-pay in the US will, "cause boards to cling to incentive-laden structures in order to minimize the risk that their compensation arrangements will be criticized by newly empowered shareholders" at 682 ). 
them to do in compensation decisions. According to Michael Dorff, "shareholders are drinking from the same well as directors and executives."184

\section{CONCLUSION}

The executive compensation literature can be divided into two camps. ${ }^{185}$ On one side is the agency cost or governance-failure school which finds that executive remuneration practices are inefficient, and claims (often without doing more than citing agency theory) that this is due to board failures. ${ }^{186}$ On the other side are scholars who argue that executive contracts are efficient, executives are not being overpaid, and their pay comes from structures that generate socially optimal results. ${ }^{187}$ This article has taken a middle course. It finds, along

184 Dorff, supra note 103 at 246.

185 See e.g. Edmans \& Gabaix, supra note 9 (contrasting the "rent extraction" school with the "optimal contracting" school at 2); Conyon, "Executive Compensation," supra note 7 (contrasting the "managerial power" view of executive remuneration decisions with the "optimal contracting" model at F62); Frydman \& Jenter, supra note 3 (contrasting the "rent extraction" view with the "competitive pay" view at 90-96).

186 See Martin J Conyon \& Simon I Peck, "Executive Compensation, Pay-for-Performance and the Institutions of Executive Pay Setting" in Thomas Clarke \& Douglas Branson, eds, The SAGE Handbook of Corporate Governance (London: SAGE Publications, 2012) 453 at 466; Kaplan, "Facts \& Challenges," supra note 177 at 137; Lucian A Bebchuk \& Michael S Weisbach, "The State of Corporate Governance Research" (2010) 23:3 Rev Financial Studies 939 at 947; Bebchuk, Fried \& Walker, supra note 23 at 753-54; Bebchuk \& Fried, Pay Without Performance, supra note 24 at 80-82; Murphy, "Politics," supra note 114 at 739; Brian J Hall, "Six Challenges in Designing Equity-Based Pay" (2003) 15:3 J Applied Corporate Finance 21 [Hall, "Equity-Based Pay"] (while equity-based pay is designed to discourage CEOs from being risk averse, it may result in the very behaviour the pay is designed to discourage, where the CEO is "unwilling to jeopardize a large anticipated payoff that will accrue even if the stock price increases at just the T-bill rate" at 29); Jensen \& Murphy, "Remuneration Fix," supra note 17 at 58. See also Gerald T Garvey \& Todd T Milbourn, "Asymmetric Benchmarking in Compensation: Executives Are Rewarded for Good Luck but not Penalized for Bad" (2006) 82:1 J Financial Economics 197 at 207-10; Kevin J Murphy, "Explaining Executive Compensation: Managerial Power Versus the Perceived Cost of Stock Options" (2002) 69:3 U Chicago L Rev 847 at 862-63; Dittmann \& Maug, supra note 132 at 328; PricewaterhouseCoopers, "Making Executive Pay Work: The Psychology of Incentives" (2012) at 6, online: <https://www.pwc.com/gx/en/hrmanagement-services/publications/assets/making-executive-pay-work.pdf $>$; Hall \& Murphy, supra note 132 at 11; Malmendier \& Tate, supra note 94 at 1595; Lund \& Polsky, supra note 103 at 718-27 (describing other ways incentive pay leads to higher compensation); Hermalin, supra note 114 at 2367-71; Peters \& Wagner, "Executive Turnover," supra note 114 at 1529; Faulkender et al, supra note 94 at 113-17; Martin, supra note 94 at 25; Dalton et al, "Performance \& Equity," supra note 81 at 18-20; Connelly et al, supra note 81 at 1564-65; Sánchez-Ballesta \& García-Meca, supra note 81 at 887-88; Habib \& Ljungqvist, supra note 94 at 2054; Hanlon, Rajgopal \& Shevlin, supra note 94 at 24. See also Tingle, "How Good?," supra note 2.

187 See John E Core \& Wayne R Guay, "Is CEO Pay Too High and Are Incentives Too Low? A WealthBased Contracting Framework" (2010) 24:1 Academy Management Perspectives 5 at 5 (there is a strong relation between performance and executive compensation, with results indicating that poor financial performance by the firm leads to decreased pay for CEOs); Lund \& Polsky, supra note 103 ("[w]e follow a traditional agency-theory framework and define an efficient ... contract as one that maximizes the net expected economic value to shareholders after transaction costs. [In other words, ] we assume that contracts minimize agency costs," n 7). See also Frydman \& Jenter, supra note 3 at 89-93 (exploring the two dominant theoretical explanations for high CEO compensation); Gabaix \& Landier, "CEO Pay," supra note 94 at 50-53; Alex Edmans, Xavier Gabaix \& Augustin Landier, "A Multiplicative Model of Optimal CEO Incentives in Market Equilibrium" (2009) 22:12 Rev Financial Studies 4881 at 4881-86; Gregory L Nagel, "The Effect of Labor Market Demand on US CEO Pay Since 1980" (2010) 45:4 Financial Rev 931 at 934; Robert H Frank \& Philip J Cook, The Winner-Take-All Society: Why the Few at the Top Get So Much More Than the Rest of Us (New York: Penguin Group, 1996) at 1-2; Steven N Kaplan \& Joshua Rauh, "Wall Street and Main Street: What Contributes to the Rise in the Highest Incomes?" (2010) 23:3 Rev Financial Studies 1004 at 1005-1007; Steven N Kaplan \& Joshua Rauh, "It's the Market: The Broad-Based Rise in the Return to Top Talent" (2013) 27:3 J Economic Perspectives 35 at 39-42; Jon Bakija, Adam Cole \& Bradley T Heim, "Jobs and Income Growth of Top Earners and the Causes of Changing Income Inequality: Evidence from US Tax Return Data" (2012) [unpublished] at 18-19, online: < https://web.williams.edu/Economics/wp/BakijaColeHeimJobsIncome GrowthTopEarners.pdf $>$ (business executives fell from 21 percent of the top 1 percent in 1979 to 11.3 percent in 2005); Luis Garicano \& Esteban Rossi-Hansberg, "Organization and Inequality in a 
with the agency cost school, that executive remuneration practices are suboptimal when their impact on corporate and executive performance is evaluated. Since these remuneration best practices are almost entirely responsible for the growth in executive pay levels, this article can conclude that executives are over-paid. In other words, companies and shareholders are not receiving value for the equity incentives and performance pay received by executives.

However, this article disagrees with the agency cost explanation for executive pay that suboptimal pay practices are due to widespread governance failures. Instead, it takes a position much closer to those on the other side of the debate: boards and executives are generally doing their best to manage potential conflicts of interest and to use the tools at their disposal to encourage superior personal and corporate performance. Boards have responded faithfully to the norms generated by finance scholars and promulgated by the media, governments, proxy advisors and institutional shareholders. The growth in executive pay is partly organically connected to these norms (such as increasing executive equity exposure, which was always going to increase pay levels) and partly as a result of these norms coming into contact with the real world of executive contracting, where the increasing risk of pay schemes must be matched by increasing potential rewards, ${ }^{188}$ and where occasional unfairness arising from forces outside of the executive's control must be ameliorated. ${ }^{189}$

It might be objected that even if boards were getting bad advice, it still represents a failure of their duty to the shareholders to persist in pay practices that are suboptimal and expensive. But this demonstrates a failure in understanding. The complaints about endogeneity from scholars wielding sophisticated statistical techniques and possessing vast amounts of data ${ }^{190}$ are evidence of the difficulty in determining the causal connection between pay practices and firm performance. Operating in an environment in which every source of authority recommends equity and performance incentives, it would not even occur to most directors to fundamentally question the received wisdom. The fact that shareholders themselves, whom most boards regard as the most important beneficiaries of their labours, are such strong supporters of these pay practices further makes it unlikely a board would abandon the recommended pay schemes. The crucial point is that the flaw in executive compensation is a widely held mistake about what works best, not CEO power unchecked by a compromised board.

Knowledge Economy" (2006) 121:4 QJ Economics 1383 at 1383-84, 1409 (differences in compensation reflect a knowledge hierarchy where organizations portray an efficient use of agents, with less able agents being left to carry out routine tasks while those with more talent specialize in problem solving); Piketty \& Saez, supra note 6 at 461; Conyon, Core \& Guay, supra note 138 at 404; Nuno Fernandes et al, "Are US CEOs Paid More? New International Evidence" (2013) 26:2 Rev Financial Studies 323 at 334; Conyon, "Compensation \& Incentives," supra note 133 at 27-29.

188 See Hermalin, supra note 114 at 2367-71; Peters \& Wagner, supra note 114 at 1529; Bebchuk \& Fried, "Agency Problem," supra note 23 at 73; Murphy, "Politics," supra note 114 at 739; Hall, "Equity-Based Pay," supra note 186 at 29; Conyon, "Compensation \& Incentives," ibid at 27-28; Jensen \& Murphy, "Remuneration Fix," supra note 17 at 58; Frydman \& Jenter, supra note 3 at 91; Garvey \& Milbourn, supra note 186 at 211-12; Dittmann \& Maug, supra note 132 at 328; PricewaterhouseCoopers, supra note 186 at 6; Hall \& Murphy, supra note 132 at 11 . See also supra note 98.

See Malmendier \& Tate, supra note 94 at 1595; Jenter \& Kanaan, supra note 97 at 2157; Lund \& Polsky, supra note 103 at 718-27. See also Bebchuk \& Fried, Pay Without Performance, supra note 24 at 139; Faulkender et al, supra note 94 at 113-17; Martin, supra note 94 at 25; Dalton et al, "Performance \& Equity," supra note 81 at 18-20; Connelly et al, supra note 81 at 1564-65; SánchezBallesta \& García-Meca, supra note 81 at 887-88; Habib \& Ljungqvist, supra note 94 at 2054; Hanlon, Rajgopal \& Shevlin, supra note 94 at 24; Frydmen \& Jenter, supra note 3 at 90-93. See e.g. Frydman \& Jenter, supra note 3. 
The second conclusion that can be drawn from the argument of this article is that boards should be liberated as much as possible from the constraining influence of the governance industry. It is highly unlikely that the governance industry will change its recommendations very quickly, as many parts of the industry (such as proxy advisors and third party compensation advisors) are economically dependent on promulgating best practices, preferably as recondite as possible. ${ }^{191}$ Furthermore, other parts of the industry (such as the managers of institutional shareholders) have few incentives to really engage on corporate governance matters, particularly to the degree required if one-size-fits-all practices are abandoned. ${ }^{192}$ Given the fact, therefore, that the governance industry will continue to advocate for remuneration best practices unsupported by empirical evidence, boards should be given as much independence as possible from the industry. ${ }^{193}$

I have argued elsewhere that boards should be permitted to make the case against the application of proxy advisor best practices in the actual document sent to investors in connection with their vote. ${ }^{194}$ This would permit some scope for what Andrew Lund and Gregg Polsky refer to as the "irreducible level of idiosyncrasy" in employment agreements. ${ }^{195}$ This reform would also necessitate proxy advisors giving boards visibility on their voting recommendations prior to distribution.

Securities regulators should replace detailed executive compensation report requirements with a set of broad principles, and allow companies and their investors to work out how the company's compensation decisions can best be explained. ${ }^{196}$ There are many reasons to suppose companies, dependent on the market for money and motivated to improve their share price, will deliver the information their shareholders need. ${ }^{197}$ Therapeutic disclosure, like the requirement to add a corporate performance graph in the annual compensation report, should be abandoned. Most of the numerous changes made to compensation disclosure requirements over the past twenty years fall into the category of therapeutic disclosure, and regardless, they have not made any difference to the growth in pay or the use of suboptimal structures. However, they have made annual reporting much more expensive, and have probably encouraged the dysfunctional compensation practices this article discusses.

Securities commissions in Canada should continue to refuse to introduce say-on-pay votes, as these mostly have the effect of giving more power over the remuneration process to the proxy advisors and institutional shareholders that are the principal advocates for suboptimal pay practices. Commissions should also revoke the various instruments on corporate governance passed in the febrile atmosphere following the Enron-era scandals. ${ }^{198}$ The

See Bryce C Tingle, "The Agency Cost Case for Regulating Proxy Advisory Firms" (2016) 49:2 UBC L Rev 725 [Tingle, "Agency Cost Case"]; Lund \& Polsky, supra note 103 at 713-14 (detailing pressures on proxy advisors and compensation consultants to provide one-size-fits-all advice).

192 Tingle, "Agency Cost Case," ibid; Tingle, "Proxy Advisors," supra note 27.

193 It is worth noting, for example, that pay-for-performance, equity incentives, compensation committees, independent directors, and say-on-pay votes were all, as we have seen, amply contradicted by the empirical literature at the very moments they were being advocated for by the governance industry. Tingle, "Proxy Advisors," supra note 27 at 748; Tingle, "Agency Cost Case," supra note 191.

Lund \& Polsky, supra note 103 at 712 . See also Frydman \& Jenter, supra note 3 at 88 (describing how evaluating CEO compensation requires considering non-public factors such as the marginal product of the CEO's efforts, as well as the CEO's risk aversion, cost of effort, net worth, and so on). This paragraph is quoted verbatim from Tingle, "How Good?," supra note 2. Competitive Federalism for Securities Regulation (Washington, DC: AEI Press, 2002) at 16-34. 
Canadian Securities Administrators proposed doing this in $2008,{ }^{199}$ and it is time to take this up again. If these policies are left in place, they lend countenance not just to the actual suboptimal practices described in this article, but to the general idea that boards cannot, as a general rule, be trusted to act in the best interests of the company and its investors.

Institutional investors should take a hard look at their internal resources and investment horizon. If they cannot dedicate the resources to making informed, particularized voting decisions, they should refrain from voting. This would reduce their costs, increase their profits, and hopefully improve the performance of the companies in their portfolio. The SEC recently advised institutional investors that they did not need to vote their shares: "an investment adviser and its client may agree that the time and costs associated with the mechanics of voting proxies with respect to certain types of proposals or issuers may not be in the client's best interests." 200 This logic should be made explicit in Canada as well. and Companion Policy 52-110CP Audit Committees, OSC CSA Notice, (2008) 31 OSCB 12158 (19 December 2008); CSA Staff Notice 58-305 - Status Report on the Proposed Changes to the Corporate Governance Regime, OSC CSA Staff Notice, (2009) 32 OSCB 9347 (13 November 2009). 
